\title{
Work Interpersonal Relationships: Cognitive Appraisals and the Prediction of Dispositional Forgiveness and Satisfaction of Life and Work
}

\author{
Georgia Stephanou1, Stamatia Giorgali² \\ ${ }^{1}$ Faculty of Humanities and Social Sciences, University of Western Macedonia, Florina, Greece \\ ${ }^{2}$ Hellenic Open University, Patra, Greece \\ Email: gstephanou@uowm.gr
}

How to cite this paper: Stephanou, G., \& Giorgali, S. (2020). Work Interpersonal Relationships: Cognitive Appraisals and the Prediction of Dispositional Forgiveness and Satisfaction of Life and Work. Psychology, 11, 1991-2023.

https://doi.org/10.4236/psych.2020.1112125

Received: November 23, 2020

Accepted: December 26, 2020

Published: December 29, 2020

Copyright $\odot 2020$ by author(s) and Scientific Research Publishing Inc. This work is licensed under the Creative Commons Attribution International License (CC BY 4.0).

http://creativecommons.org/licenses/by/4.0/

\begin{abstract}
This study examined the employees' attributions for their subjectively perceived interpersonal relationships with their colleagues as best or worst, and the role of dispositional forgiveness (self, other, situations) in predicting the perceived quality and the attributions of the same interpersonal relationships, as well as the extent to which life satisfaction and work satisfaction were predictive of the same appraisals of the relationships. The participants were 200 secondary school teachers, of both genders, who were members of the current organization for at least 2 years. The results revealed that 1) the best interpersonal relationships were mainly attributed to internal, personal controllable, stable and self-colleague controllable factors, whereas the worst interpersonal relationships were predominately attributed to external, personal uncontrollable and colleagues' controllable factors, and mainly locus of causality discriminated the two groups of relationships, 2) employees who were higher forgiving (mainly, situations) enjoyed more their best- and suffered less their worst-colleaguing relationships than the employees who were comparatively lower in forgiving 3) high forgiving teachers made adaptive attributional appraisals for the worst and, particularly, best interpersonal relationships, 4) the valence of the prediction of forgiveness of self, of other and of situations varied between and within the attributional dimensions as well as it varied between and within worst and best interpersonal relationships and 5) relative to forgiveness, life satisfaction, and, particularly, work satisfaction were weak predictors of the appraisals of the colleaguing relationships, mainly in the worst. Implication of these results in workplace and personal well-being are discussed.
\end{abstract}

\section{Keywords}

Workplace Interpersonal Relationships, Attributions, Forgiveness, Life 
Satisfaction, Work Satisfaction

\section{Introduction}

Examining employees' interpersonal relationships with their colleagues may contribute to explaining their professional life, and enhancing their happiness and subjective well-being, as past researches support (Aldrup, Klusmann, \& Lüdtke, 2017; Aspinwall \& Staudinger, 2003; Diener, Lucas, \& Oishi, 2005; Seligman, 2002, 2005). Investigating, specially, their perceptions of the interpersonal relationships may help understand their professional and emotional lives and development, since happy workers and people are those who report fulfilling relationships (Buss, 2005; Claessens, Van Tartwijk, Van der Want, Pennings, Verloop, Den Brok, \& Wubbels, 2017; Diener, 2000; Diener \& Seligman, 2002; Fletcher \& Thomas, 1996; Lucas, Dyrenforth, \& Diener, 2008; Saphire-Bernstein \& Taylor, 2013). Further, focusing on employees' attributions for their interpersonal relationships with their professional colleagues may be important for understanding work and relationship behavior, and it may explain how these relations can develop and sustain (Fincham, 2001, 2003; Fitness, Fletcher, \& Overall, 2005; Karney, McNulty, \& Bradbury, 2003; Schunk \& Zimmerman, 2006; Trope \& Guant, 2005; Wang \& Hall, 2018).

In education, the high quality of the wide variety of the interpersonal relationships, such as teacher and students, teachers and parents, school leaders and teachers, and teachers and their colleagues, are considered essential for the healthy development of teachers and students (Martin, 2014; Pennings, Brekelmans, Sadler, Claessens, van der Want, \& van Tartwijk, 2018; Stephanou \& Athanasiadou, 2020; Wubbels, Brekelmans, den Brok, Levy, Mainhard, \& van Tartwijk, 2012). Further, positive relations among teachers are estimated as an important element of school functioning, and a potential source of school improvement (Moolenaar, Daly, Sleegers, \& Karsten, 2014). However, although the high importance of the interpersonal relationships in education has been widely recognized, from a variety of perspectives, most of the existence literature devoted to studying the teacher-student relationship and its consequences on student outcomes, while the interpersonal relationships of teachers with their teaching colleagues have been hardly investigated (Friedman, 2000; Martin \& Collie, 2019; Kyriacou, 2001; Pennings et al., 2018; Van Maele, Moolenaar, \& Daly, 2015; Veldman, Van Tartwijk, Brekelmans, \& Wubbels, 2013; Zandvliet, den Brok, Mainhard, \& van Tartwijk, 2014).

Therefore, this study focuses on the teachers' intuitive and attributional appraisals of their interpersonal relationships with their colleagues, since both appraisals have been central constructs in research in social and close interpersonal relationships and contribute into development and quality of these relationships (Collins, Ford, Guichard, \& Allard, 2006; Fincham, 2003; Greitemeyer \& Weiner, 
2003; Harvey, 1987; Harvey \& Omarzu, 1999; Harvey, Pauwels, \& Zickmund, 2005; Karney et al., 2003; Stephanou, 2012; Stephanou \& Athanasiadou, 2020; Wee, 2017; Weiner, 2014). Whether partners perceive their relationship as positive or negative, and which explanations or interpretations they make about a given relationship influence their emotions, motivation and behaviour (Blascovich \& Mandess, 2000; Fincham, 2003; Fitness, Fletcher, \& Overall, 2005; Fletcher, Fitness, \& Blampied, 1990; Fletcher \& Thomas, 2000; van Doorn, van Kleef, \& van der Pligt, 2015; Wang \& Hall, 2018). For example, attributing a good interpersonal relationship to self-internal factors leads to the emotions of confidence and pride, whereas external attributions are related to positive behaviors, such as help seeking, or negative responses, such as helplessness, avoidance and lack of persistence. On the contrarily, attributing a bad interpersonal relationship to inadequate self-factors predicts incompetence, shame, guilt and resignation, whereas attributing unsuccessful events to others causes aggression and vindictiveness (Fincham, 2003; Fitness et al., 2005).

This investigation also encompasses individual differences in interpersonal relationships because such factors, as a component of the cognitive schemas individuals develop of themselves and others, influence how they feel, cognitively interpret, and behave in relational situations, particularly in negative or ambiguous situations (Demir, 2008; Schoebi \& Randall, 2015; Timmermans, Van Mechelen, \& Kuppens, 2010). Forgiveness in interpersonal interactions is considered as an important source of "maintain relatedness with fellow humans in the face of being harmed by them" (Fincham et al., 2005). To maintain a positive relationship, it seems dysfunctional to hold the transgressor entirely responsible for an offense. Based on Lichtenfeld, Maier, Buechner and Fernández-Capo's (2019) argument, forgiveness should lead to a change in causal attributions toward the offender. Further, forgiveness is one of the constructive ways of moderating workplace conflict and encouraging more positive cooperative behaviors (Butler \& Mullis, 2001), and of repairing broken relationships with work colleagues and overcoming debilitating thoughts and emotions resulting from interpersonal injury (Aquino, Grover, Goldman, \& Folger, 2003). Also, forgiveness is positively related to functioning at work (Thompson \& Shahen, 2003). However, there is a limited research in forgiveness within the workplace and organizations, particularly in education (Aquino, Tripp, \& Bies, 2001; Aquino et al., 2003; Boonyarit, Chuawanleeb, Macaskillc, \& Supparerkchaisakul, 2013; Cameron \& Caza, 2002). Therefore, this study examines the role of forgiveness in the cognitive appraisals of interpersonal relationships. Accurately, this investigation deals with trait forgiveness or forgivingness which is a general disposition to forgive one's trespassers over time and across various situations (Berry, Worthington, Parrott, O'Connor, \& Wade, 2001), expanding from past researches on situational forgiveness, which happens after a specific or certain offense. The dispositional perspective of forgiveness is also based on the increasing research interest in forgivingness, which conceivably is more powerful predictor of long-term 
behavioral patterns. In consistency with the conceptualization of forgiveness by Thompson, Snyder, Hoffman, Michael, Rasmussen et al. (2005), this study also differentiates forgiveness of self, of situations and of other, and it does not consider forgiveness merely as a global construct.

Also, as employees enter into interpersonal interactions or relationships with their colleagues, their work experience and life experiences affect how they interact with the colleagues and how they construe their psychosocial world at workplace (Kalish \& Robins, 2006; Moolenaar et al., 2014). This study involves life satisfaction and work satisfaction which, involving emotional states, feelings, affective responses, and cognitive evaluations of work (Irving \& Montes, 2009), are related to the need for relationship and work interpersonal relationships (Hombrados-Mendieta \& Cosano-Rivas, 2013; Stephanou, Gkavras, \& Doulkeridou, 2013; Unanue, Gómez, Cortez, Oyanedel, \& Mendiburo-Seguel, 2017). Accurately, based on the Bérubé, Donia, Gagné, Houlfort, and Koestner' (2007) conceptualization of work satisfaction, the present investigation focuses on the cognitive appraisal of a person's work situation rather than on specific job satisfaction. This approach is in consistency to Diener, Emmons, Larsen and Griffin' (1985) notion of life satisfaction which refers to people's conscious evaluative judgments of their lives using their own personal criteria. This approach to satisfaction is also considered the most appropriate for the present study, since the target group consists of employees with a certain teaching career in the certain domain of education (Bérubé, Donia, Gagné, Houlfort, \& Lvina, 2016).

Conclusively, the present research extends existing empirical work on employees' interpersonal relationships with their colleagues by focusing on the cognitive appraisals of these relationships and the role of dispositional forgiveness on the cognitive processes. The possible effects of life satisfaction and work satisfaction on the above appraisals were also examined.

\subsection{Intuitive and Attributional Appraisals of Interpersonal Relationships}

Theories on intimate relationships conceptualize how interdependent actions and their appraisal shape affective experience and related relationship behaviors (Schoebi \& Randall, 2015). The theoretical basis of this study is the Weiner's (2001, 2010, 2014) attribution theory which, incorporating cognitive appraisals, contributes to understanding interpersonal relationships (Fincham, 2003; Fitness et al., 2005; Schunk \& Zimmerman, 2006; Stephanou, 2012; Wang \& Hall, 2018). Weiner's $(1992,2001,2010,2014)$ attribution theory is a comprehensive theoretical framework for understanding motivation for achievement outcomes from the intrapersonal perspective, which refers to the attributions individuals make for their performance, and from the interpersonal perspective, which concerns the attributions made for outcomes experienced by others, and how perceptions of another's responsibility for an outcome contributes to other-directed emotions (gratitude, sympathy, anger) and behaviors (punishment, support) (Fincham, 2003; Schunk \& Zimmerman, 2006; Wang \& Hall, 2018). 
Individuals appraise an interpersonal relationship by evaluating and by attributing causes (Fincham, 2001; Leary, 2000; Smith \& Lazarus, 1990; Trope \& Gaunt, 2005; Schoebi \& Randall, 2015). The appraisals reflect what the stimulus-relationship-means to the individual and whether it is good or bad (Fincham, 2003; Fitness et al., 2005). The valence of an event has an impact on the initial emotional response, such as a negative event produce happiness, while the negative one is linked to frustration and sadness, but the perceived dimensions underlying the causes of the event determine the specific affect experienced (Fincham, 2003; Weiner, 2014).

An interpersonal relationship could be attributed to infinite number of factors, but self, other person, situation, environment, self-other person interaction, and relationship itself are the dominant causes in describing positive and negative relationships (Argyle, 2001; Erber \& Gilmour, 1995; Planalp \& Rivers, 1996; Stephanou, 2012). However, as above mentioned, the causes per se are not crucial, as the location of the causes on attributional dimensions which have psychological and behavioral consequences which have psychological and behavioral consequences (Argyle, 2001; Berscheid \& Ammazzalorso, 2003; Fletcher \& Thomas, 2000; McAuley, Duncan, \& Russell, 1992; Weiner, 2002, 2005). In Weiner's $(2002,2014)$ theory, attributions are categorized into causal dimensions of locus of causality (internal/external to the person), stability (stable/unstable over time) and controllability (personal and external controllable/uncontrollable).

Findings to date have shown that the perceived quality of the relationship has an impact on the attributional pattern (Fiedler, Semin, Finkenauer, \& Berkel, 1995; Fincham, 2003; Macnow, 2019). Specifically, partners exhibit self-enhancing and self-saving biases (Dix \& Grusec, 1985), when making attributions for positive and negative interpersonal relationships or the other's behavior. Specifically, individuals tend to attribute the positive interpersonal relationships to themselves (internal, stable, personal controllable, and external uncontrollable), and the negative relationships to the partner- and situational-related factors (Fitness et al., 2005; Gagné \& Lydon, 2004; Stephanou, 2005, 2011; Stephanou \& Athanasiadou, 2020; Weiner, 2001, 2002; Ybarra \& Stephan, 1999). However, according to some theorists, although the attributional biases of partner, has been repeatedly found in different relationship situations (Fincham, 1985; Macnow, 2019), this bias may have affect satisfaction in relationships, or it could serve as a secondary indicator that the relationship is already distressed. Specifically, the more negative the interpersonal relationship the more the attributions to the other person's constant negative properties (Argyle, 2001; Gilbert \& Malone, 1995; Hewstone \& Antaki, 2001; Williams \& Gilmore, 2008). Gottman (1994: p. 184), examining what makes marital conflict dysfunctional supports "the response to one's partner with criticism, disgust, contempt, defensiveness and stonewalling", which the one influences the other in that row.

As above mentioned, the research in education regarding teachers' appraisals for their relationships with the teaching colleagues is extremely limited. The vast 
majority of studies in teachers' interpersonal attributions have devoted to student achievement- and social-related behavior. The existence research in the field indicates that teachers tend to attribute a student failure to factors internal to the student (e.g., student ability, effort) or family influences than teacher- and school-related issues as well as they make internal to the students and stable attributions when explaining performance that matches their own original expectations toward the students (ability, consistent effort, student personality). In the case of success, although teachers take responsibility for student success (e.g., instructional quality), they, at the same time, give credit to students' positive proprieties (e.g., student ability, effort) (see Wang \& Hall, 2018 for a review). Stephanou and Athanasiadou (2020), examining teacher-student interpersonal relationships from the teachers' perspective, revealed that the positive interpersonal relationships were predominately attributed to stable, personally controllable and self-student controllable factors, whereas the negative interpersonal relationships were in the most attributed to external, external controllable, unstable, and self-student controllable factors.

In sum, both empirical and theoretical work in attributions for interpersonal relationships support that the belief that a person-teacher-has about the causes of his/her interpersonal relationship influences his/her emotions for the partner-colleague-and his/her expectations for the quality of the relationship in the future (Fletcher, 2002; Siemer, Mauss, \& Gross 2007; Stephanou, 2011; Wang \& Hall, 2018; Weiner, 2001, 2014). Then, emotions and expectations influence the individual's actual behavior toward the partner, and the relationship itself (Fincham, 2003; Fletcher \& Clark, 2002; Fletcher \& Thomas, 2000; Weiner, 2001, 2014). However, although all attributional dimensions are related to emotions for the partner's (student) behavior and the relationship itself, their prevalence differs across the various emotions (Berndsen \& Manstead, 2007; Weiner, 2005, 2006, 2014). Precisely, stability most impact on performance expectations and the emotions of hopefulness/hopelessness, controllability affects perceptions of personal responsibility and the social-related emotions, such as shame, anger and gratitude, while locus of causality mainly influences perceptions of personal competence and the self-related emotions, such as pride in success.

\subsection{Association of Forgiveness with Cognitive Appraisals of Interpersonal Relationships}

This study, extending previous studies on forgiveness after a specific offense, is interested in trait forgiveness, or forgivingness (Roberts, 1995), which is the global disposition to forgive across multiple offences occurring in a variety of relationships and interpersonal situations. Furthermore, expanding from the majority of research which has focused on forgiveness of another person for a specific transgression (Kaleta \& Mroz, 2018; Webb, Bumgarner, Conway-Williams, Dangel, \& Hall, 2017), the current study, in consistency with Thompson et al. (2005), conceptualizes forgiveness as a multidimensional construct composed of forgiveness of self, others, and situations beyond anyone's control. Forgiveness is 
distinct from other related constructs, such as condoning, excusing and forgetting, as well as it differs from the various defense mechanisms, such as denial, dissociation and repression (see Freedman \& Zarifkar, 2016 for a review).

The existence research has documented the beneficial role of forgiveness to various aspects of one's life. High level of forgiveness is associated with benefits in anxiety and depression (Freedman \& Enright, 1996; Reed \& Enright, 2006; Rye \& Pargament, 2002), and in physical, mental health and well-being (Berry \& Worthington, 2001; Fincham et al., 2005; Lawler-Row \& Piferi, 2006; Lawler-Row, Younger, Piferi, Jobe, Edmondson, \& Jone, 2005; Thoresen, Harris, \& Luskin, 2000; Toussaint, Shields, Dorn, \& Slavich, 2016a; Witvliet, Phipps, Feldman, \& Beckham, 2004). Forgiveness is also positively related to optimism, hope and gratitude (Hill \& Allemand, 2010; Rye, Loaicono, Folck, Olszewski, Heim, \& Madia, 2001; Szcześniak \& Soares, 2011; Toussaint \& Friedman, 2009; Wohl, DeShea, \& Wahkinney, 2008), and to personality traits of agreeableness, extraversion and conscientiousness (Balliet, 2010; Brose, Rye, Lutz-Zois, \& Ross, 2005), while it is negatively linked to neuroticism (Fehr, Gelfand, \& Nag, 2010).

Similarly, several studies have revealed the link between forgiveness and high quality of close relationships (Fincham, Beach, \& Davila, 2004), improved marital quality (Fincham \& Beach, 2007), ongoing relationships (Rusbult, Arriaga, \& Agnew, 2003), interpersonal adjustment (Tse \& Yip, 2009) and restoring a social relationship (Raj \& Wiltermuth, 2016; Tsang, McCullough, \& Fincham, 2006).

The existence empirical evidence in organizational research indicates that forgiveness is related to better health and personal well-being at the organizational level, and it contributes to a more fulfilling workplace climate (Mróz \& Kaleta, 2019; Stone, 2002; Thompson \& Shahen, 2003). The organizational research, however, has mostly focused on revenge as a response to interpersonal offenses (Bies \& Tripp, 1997; Skarlicki \& Folger, 1997; Tripp \& Bies, 1997), while there is a limited amount of research in forgiveness within the workplace (Aquino et al., 2001; Boonyarit et al., 2013; Bradfield \& Aquino, 1999; Toussaint et al., 2016b).

As above mentioned, forgiveness has been found to increase the likelihood of quality of interpersonal relationships. Forgiveness becomes an essential consideration in the workplace context, where long term interpersonal relationships develop, and where an employee-teacher-who have been seriously harmed by a working colleague often have to continue interacting as a requirement of their jobs. Workers who forgive overcome debilitating thoughts and emotions resulting from interpersonal injury and are likely to repair damaged relationships with their colleagues (Aquino et al., 2001; Thompson et al., 2005).

Forgiveness has been linked to attributions that impact intimate relationships (Bell, Kamble, \& Fincham, 2018; Friesen, Fletcher, \& Overall, 2005; Lichtenfeld et al., 2019). Forgiveness and attributions have been examined previously as they relate to marital quality (Bell et al., 2018; Fincham, 2001). The existent empirical work reports the influential role of attributions in forgiveness in romantic relationships (Fincham, Paleari, \& Regalia, 2002; Friesen et al., 2005; Hall \& Fin- 
cham, 2006), and reveals the negative impact of the responsibility attributions on forgiveness (Bradfield \& Aquino, 1999; Fehr et al., 2010; McCullough, Fincham, \& Tsang, 2003). Fincham et al. (2002) found that, in married couples, forgiveness was directly and indirectly related to responsibility attributions via affective reactions and empathy. Also, greater perceptions of partner responsibility for transgressions were related to less forgiveness, and less-blaming male partners had more-forgiving female partners (Friesen et al., 2005). Similarly, in a sample of adult workers, Iwai and Carvalho (2020) revealed that attributions of behavioral stability to the offender play a mediating role in the relationship between implicit theories and forgiveness, while stability attributions do not decrease the victims' desires to seek revenge against offenders. Generally, attributions may impact on explaining an event-causal attributions-or assigning accountability-responsibility attributions-for an event (Fincham, 2001).

In sum, attributions have been more widely considered as distinct construct affecting the forgiveness process rather than as features of it (Lichtenfeld et al., 2019). A limited amount of studies or theoretical models have ever considered the reciprocity of this relationship and examined if forgiveness predicts a victim's attributions. For example, a study by Wenzel, Turner and Okimoto (2010) examined the effect of forgiveness on attributions via a longitudinal study. However, in this study, only the effect of forgiveness on attributions of severity, but not on responsibility attributions, were found. Hall and Fincham (2005) have proposed that self-forgiveness originate from shame and guilt that are caused by attributions and the severity of the transgressions. They further argued that guilt and conciliatory behaviours toward a victim and perceived forgiveness may facilitate or inhibit self-forgiveness.

Overall, both empirical and theoretical work suggests a relationship between attributions and forgiveness. However, it is not clear whether or not forgivingness precedes, results from, or merely correlates with attributions. This study expands findings and supports that attributions for the work interpersonal relationships are resulted from the employee's disposition to forgive. It could be hypothesized that if a working teacher forgives a colleague or self or situation it seems adaptive to change his/her attributions about the event accordingly and serve the evolutionary goal of forgiveness to reestablish the relationship. Probably, a high-forgiving teacher attributes the negative interpersonal relationships to external, unstable and specific factors instead of internal, stable and global factors.

\subsection{Association of Life Satisfaction and Work Satisfaction with Cognitive Appraisals of Interpersonal Relationships and Forgiveness}

Life satisfaction refers to the judgment that an individual does about his/her life in several domains (Diener, Inglehart, \& Tay, 2013; Diener \& Tay, 2012), and it is rather a cognitive than a simple report of one's feeling state, leading some researchers to label it "cognitive well-being" (Luhmann, Hofmann, Eid, \& Lucas, 
2012). Diener (1994) considers satisfaction to represent the cognitive component of one's well-being, and affect to represent its emotional counterpart, while, according to Helliwell, Layard and Sachs (2013), life satisfaction is a significant contributor to subjective well-being. Similarly, work satisfaction refers to cognitive appraisal of a person's work (Bérubé et al., 2016), and it differs from job satisfaction which refers to the employees' feelings and thoughts about their specific work (Irving \& Montes, 2009; Weiss, 2002). This research, in consistency with life satisfaction, and, considering that the participants have a certain career in the certain domain of education, focuses on work satisfaction. In the literature, job satisfaction and work satisfaction have been indiscriminately used each other.

Life satisfaction is positively related to several desirable companies' results, such as career satisfaction, organizational commitment and, particularly, job satisfaction (Diener \& Tay, 2012). Similarly, job satisfaction is a beneficious to various organization-related factors, such as job performance, work engagement and organizational citizenship behavior, and to life satisfaction (Erdogan, Bauer, Truxillo, \& Mansfield, 2012; Heller, Judge, \& Watson, 2002; Judge \& Bono, 2001; Mafini \& Pooe, 2013; Swaminathan \& Jawahar, 2013), while it is inversely associated within underproductive, interpersonal and organizational behaviors (Mount, Ilies, \& Johnson, 2006). Past researches in the working context of education evident that satisfied teachers display high levels of job commitment, are less at risk of leaving the profession (Gersten, 2001; Reeve \& Su, 2014; Singh \& Billingsley, 1996; Skaalvik \& Skaalvik, 2011), experience low level of occupational stress (Klassen \& Chiu, 2010; Van Houtte, 2006) and experience positive emotions for their work context (Stephanou et al., 2013).

Positive social and interpersonal relationships in workplace are beneficial for workers (Gagne, 2018; Kaleta \& Mróz, 2018; Szostek, 2019). For example, Hombrados-Mendieta and Cosano-Rivas (2013) show that workplace support protects job satisfaction and life satisfaction against the negative effects of burnout, while Di Fabio and Kenny (2016) note that the need for relationship and the need for self-determination are significant contributors to workers' well-being. Further indication that both constructs are associated with work interpersonal relationships comes from Unanue et al. (2017), underlying the impact of psychological needs as stated by self-determination theory (Deci \& Ryan, 2000) on the life-job satisfaction link. Similarly, interpersonal relationships in a key element in the work of teachers (Van Droogenbroeck, Spruyt, \& Vanroelen, 2014). More precisely, working teachers' positive relationships with co-workers, parents, and students mitigates some of the adverse effects of teaching work (Cano-García, Padilla-Muñoz, \& Carrasco-Ortiz, 2005; Gavish \& Friedman, 2010; Skaalvik \& Skaalvik, 2011), and it is a key variable influencing their job satisfaction (Ghenghesh, 2013; Hargreaves, 2000; Luthans, 2005; Veldman et al., 2013), while the problematic teacher-student relationships are associated with teacher work stress and negative emotions (Friedman, 2006; Yoon, 2002). 
However, it is not unclearly whether or not life or work satisfaction precedes, results from, or merely correlates with work interpersonal relationships, and the subsequent appraisal. Life satisfaction and work satisfaction, involving cognitive evaluation proceeds, might influence colleaguing interpersonal relationships and the appraisals of these relationships in an adaptive way. Besides, life and work experiences affect how employees interact with the colleagues and how they enter into interpersonal relationships with them (Moolenaar et al., 2014).

The association of forgiveness with life and work satisfaction beyond the aim of this study. However, it is mentioned that dispositional forgiveness is positively correlated to life satisfaction (Allemand, Hill, Ghaemmaghami, \& Martin, 2012; Ayten \& Ferhan, 2016; Szcześniak \& Soares, 2011) and job satisfaction (Cox, 2011; Mróz \& Kaleta, 2019). Further, forgiveness could enable an individual to maintain relation and leads to life satisfaction (Kaleta \& Mróz, 2018). Also, Guchait, Madera and Dawson (2016) found that employees who perceived their organization to be forgiving of mistakes, errors, and offences were less likely to leave their jobs, and more likely to be connected to their organization and be satisfied with their job.

\subsection{Aim and Hypotheses of the Study}

The main aim of the present study was the examination of the employees' attributions for their subjectively perceived interpersonal relationships with their colleagues as best or worst, and the role of dispositional forgiveness (self, other, situations) in the generation of the perceived interpersonal relationships as best or worst and the subsequent attributions. The possible effects of life satisfaction and work satisfaction in the above interpersonal relationships and in the subsequent attributions were also examined.

Based on the above literature review, the hypotheses of the study were the following.

The subjectively estimated interpersonal relationships as best will be in the main attributed to self-related factors (internal, personally controllable, stable), whereas the perceived interpersonal relationships as worst will be most ascribed to colleague-related or external factors (Hypothesis 1a). The group with the best interpersonal relationships will be predominately discriminated from the group with the worst interpersonal relationships by the attributional dimension of locus of causality than by the rest of the attributional dimensions (Hypothesis 1b).

Forgiveness, life satisfaction and work satisfaction, as a group, will have positive effect on the formulation of the estimated interpersonal relationships as best and worst but their influential power will vary between and within the best and the worst interpersonal relationships, with life satisfaction being the least favouring (Hypothesis 2a). Forgiveness (self, other, situation) will contribute into the generation of the best and the worst interpersonal relationships (Hypothesis $2 b$ ), while the valence of the prediction of forgiveness of self, forgiveness of other and forgiveness of situations will vary between and within the perceived best or 
worst interpersonal relationships, with forgiveness of other exhibiting the highest prediction (Hypothesis 2c).

Forgiveness, life satisfaction and work satisfaction, in combination, will explain an amount of the variance of the attributions for the best and worst interpersonal relationships (Hypothesis 3a). Forgiveness (self, other, situation) will contribute into the generation of an adaptive attributional pattern for the best and worst interpersonal relationships (Hypothesis $3 b$ ). The valence of the prediction of forgiveness of self, forgiveness of other and forgiveness of situations will vary between and within the attributional dimensions for the perceived best and worst interpersonal relationships (Hypothesis 3c). Forgiveness of self, forgiveness of situations and forgiveness of other will be a beneficial contributor most to locus of causality, external controllability and colleagues' locus of causality respectively than to any other attributional dimension (Hypothesis $3 \mathrm{~d}$ ).

Both life satisfaction and work satisfaction will be beneficiary factors to the formulation of the attributions for the perceived best and worst interpersonal relationships but their predictive role will differ across and within attributional dimensions (Hypothesis 4).

\section{Method}

\subsection{Participants}

The participants were 200 in service teachers who were recruited from 30 state secondary schools from various regions of Greece. They were of both genders (98 males, 102 females), aged from 29 to 60 years, and they had working experience from 2 to 28 years with balance among years of teaching experience. All respondents had been working at the current organization—school-for at least 2 years, and they teach various subjects, such as literature, mathematics, physics, chemistry, biology, physical education, sociology and technology.

\subsection{Measurements}

\subsubsection{Perceived Quality of Interpersonal Relationships}

The employees' subjective evaluation of the quality of their interpersonal relationships with their colleagues at work were examined by responding to a five-point six items scale. The responses ranged from $1=$ Not at all to $5=$ Totally (e.g., "How satisfied are you with the interpersonal relationship with the specific colleague?"). The construction of the scale was based on past researches in interpersonal relationships (Fincham, Rogge, \& Beach, 2018; Rogge et al., 2017; Stephanou, 2012), and in interpersonal relationships at work and school framework (Stephanou \& Athanasiadou, 2020; Szostek, 2019), and on the Quality of Interpersonal Relationships in the Team Scale (QIRT-S, Szostek, 2019). The participants completed the scale twice; they completed, first, the scale for the worst interpersonal relationship, and, then, the scale for the best interpersonal relationship. Cronbach's alpha value for the data of the present study was .72 and .75 
for the best and worst interpersonal relationships, respectively.

\subsubsection{Attributions for Interpersonal Relationships}

The participants made separate attributions for their best and worst interpersonal relationships with their colleagues by responding to modified Causal Dimension Scale II (CDSII, McAuley, Duncan, \& Russell, 1992). The modified version of the CDSII was based on past researches in interpersonal relationships (Fincham, 2003; Fletcher, 2002; Fletcher \& Thomas, 1996), and it has proved a reliable and valid research instrument in examining attributions for intimate interpersonal relationships in Greek population (Stephanou, 2012; Stephanou \& Athanasiadou, 2020). The scale allowed the employees to write down, according to their opinion, the most influential factor of their best or worst interpersonal relationship with their colleague, and, then, to classify that cause along the attributional dimensions of locus of causality (internal/external causes to him/herself), stability (stable/unstable cause over time), personal controllability (controllable/uncontrollable causes by himself/herself), external controllability (controllable/uncontrollable causes by others), colleague's locus of causality (internal/external cause to the colleague), colleague's controllability (personally controllable/uncontrollable cause by the colleague), self-colleague interactive locus of causality (internal/external causes to interaction of self-colleague) and selfcolleague interactive controllability (controllable/uncontrollable causes by the interaction self-colleague). Each of the eight subscales consists of three items, ranging from the negative pole $1=$ not at all (e.g., unstable) to the positive pole 9 $=$ totally (e.g., stable). Cronbach's alpha was .84 for locus of causality, .67 for stability, .76 for personal controllability, .68 for external controllability, .67 for colleague's locus of causality, .77 for colleague's controllability, .80 for self-colleague locus of causality, and .69 for self-colleague controllability.

\subsubsection{Forgiveness}

Forgiveness was estimated by the Heartland Forgiveness Scale (HFS, Thompson et al., 2005) which is a self-report measure of dispositional forgiveness. It measures the extent to which a person has the general disposition to forgive, and it assesses forgiveness of self ( 6 items), forgiveness of other ( 6 items) and forgiveness of situations ( 6 items). Responses ranged from $1=$ almost always false for me to 7 = almost always true for me (e.g., "Although I feel bad at first when I mess up, over time I can give myself some slack), with the higher scores indicating higher levels of forgiveness, and lower scores indicating lower levels of forgiveness. Cronbach's alpha value for the data of the present study was $.64, .75$ and .58 for forgiveness of self, others and situations, respectively.

\subsubsection{Life Satisfaction}

Life satisfaction was examined by the Satisfaction With Life Scale (SWLS, Diener, Emmons, Larsen, \& Griffin, 1985). The SWLS consists of five items (e.g., "In most ways my life is close to my ideal"), and it assesses satisfaction with the individual's life as a whole. Responses ranged from strongly disagree $=1$ to 
strongly agree $=7$, with the high score reflecting high level of life satisfaction. In this study, Cronbach's alpha was .79.

\subsubsection{Work Satisfaction}

The Satisfaction With the Work Scale (SWWS, Bérubé et al., 2007; Bérubé et al., 2016) was used to examine the participants' work satisfaction. This scale, which was adapted from the Satisfaction with Life Scale (Diener et al., 1985), is a reliable and valid measure of work satisfaction, and it focuses on the cognitive appraisal of a person's work situation. The scale includes 5 items (e.g., "The conditions under which I do my work are excellent"), while the responses ranged from $1=$ Strongly disagree to $7=$ Strongly agree. Cronbach's alpha was .81 in this research.

\subsubsection{Personal Factors}

The employees responded to a set of questions regarding personal and demographical factors, such as age, gender, working experience and working experience in the current organization.

\subsection{Procedure}

Data collection were performed in the middle of a school year, to ensure that the participants had enough time to form an impression about their interpersonal relationships with their colleagues. The employees filled out, initially, the scales of forgiveness, life satisfaction and work satisfaction, and, one week later, the scales of the perceived quality of their relationships with their colleagues and the subsequent attributions.

The participants themselves defined their interpersonal relationships with their colleagues at work as best or worst by responding to the interpersonal relationship scales twice. Accurately, they, first, wrote down the name of their colleague with whom they had the worst interpersonal relationship, and, then, filled out the scales that referred to this specific relationship. After that, they did the same for their best interpersonal relationship with their colleagues.

Oral and written information about the aim of this study were provided to the participants, and they were assured of anonymity and confidentiality. To match the questionnaires that were responded by the same teacher, the participants were asked to choose a code name and use it on across all of the scales.

\section{Results}

\subsection{Attributions for the Best and Worst Interpersonal Relationships}

The results from the MANOVA analysis, using the Wilks's lambda estimate, with the eight attributional dimensions as within-subjects factor and the perceived interpersonal relationship with the colleagues (best/worst) as betweensubjects factor showed significant effect of the attributional dimensions, F (7, $192)=38.60, p<.01, \eta^{2}=.32$, significant effect of the perceived interpersonal 
relationship, $\mathrm{F}(1,199)=280.00, p<.01, \eta^{2}=.45$, and significant multivariate effect, $\mathrm{F}(7,192)=21.35, p<.01, \eta^{2}=.27$.

To clarify the above findings, ANOVAs and Discriminant Function analysis (using stepwise method), with the perceived interpersonal relationship (best/worst) as grouping variable and the attributional dimensions as predictor variables, were performed. Observation of the results from these analyses and the mean scores on Table 1 indicates that the employees made external to their colleagues, slightly external controllable and controllable by their colleagues, internal to self-colleague interaction, and, mainly, internal to themselves, personal controllable, stable and self-colleague controllable attributions for their best interpersonal relationships with their colleagues. On the contrary, they attributed their worst interpersonal relationships with their colleagues to internal to their colleagues, internal and controllable to self-colleague, external controllable, stable and, predominately, external to themselves, personal uncontrollable and colleagues' controllable factors. In addition, the results from the discriminant analysis revealed that locus of causality, discriminating power $=.59$, followed by colleague's controllability, discriminating power $=.36$, personal controllability, discriminating power $=.25$, and colleague's locus of causality, discriminating power $=.23$, was the most powerful attributional dimension in discriminating the group with the best interpersonal relationships from the group with the worst interpersonal relationships. It was also found that the attributional dimensions of stability, external controllability and self-colleague interactive controllability had no significant contribution in discriminating the two groups of interpersonal

Table 1. Results from Discriminant Function analysis for the employees' attributional dimensions for the estimated best and worst interpersonal relationships with their colleagues.

\begin{tabular}{|c|c|c|c|c|c|c|c|}
\hline \multirow[t]{2}{*}{$\begin{array}{c}\text { Attributional } \\
\text { dimensions }\end{array}$} & \multicolumn{2}{|c|}{$\begin{array}{l}\text { Best } \\
\text { interpersonal } \\
\text { relationships }\end{array}$} & \multicolumn{2}{|c|}{$\begin{array}{l}\text { Worst } \\
\text { interpersonal } \\
\text { relationships }\end{array}$} & \multirow[t]{2}{*}{$\begin{array}{l}\text { Wilks' } \\
\text { Lambda }\end{array}$} & \multirow[t]{2}{*}{$\begin{array}{c}\text { Discriminating } \\
\text { power }\end{array}$} & \multirow[t]{2}{*}{$F$} \\
\hline & Mean & SD & Mean & SD & & & \\
\hline Locus of causality & 6.78 & .83 & 3.65 & 1.10 & .29 & .59 & 771.50 \\
\hline Personal controllability & 6.07 & .90 & 4.10 & 1.29 & .72 & .25 & 158.10 \\
\hline Stability & 6.70 & .92 & 6.35 & .73 & .95 & $.09^{*}$ & 19.48 \\
\hline External controllability & 5.65 & 1.10 & 6.15 & .75 & .94 & $.09^{*}$ & 24.20 \\
\hline Colleague's locus of causality & 4.40 & .77 & 6.05 & .82 & .73 & .23 & 151.50 \\
\hline $\begin{array}{l}\text { Colleague's personal } \\
\text { controllability }\end{array}$ & 5.10 & .93 & 6.96 & .99 & .51 & .36 & 371.95 \\
\hline $\begin{array}{l}\text { Self-colleague interactive } \\
\text { locus of causality }\end{array}$ & 5.96 & .88 & 5.95 & 1.15 & .99 & .02 & .06 \\
\hline $\begin{array}{l}\text { Self-colleague interactive } \\
\text { controllability }\end{array}$ & 6.35 & 1.05 & 5.90 & .91 & .95 & $.08^{*}$ & 19.65 \\
\hline
\end{tabular}

Note: $\mathrm{F}(1,398)>19.48, p<.01 ; \mathrm{F}(1,398)=.06, p>.05 ;{ }^{*}$ : no significant contribution in discriminating the two groups. 
relationships, although these attributions differed between the two groups.

Accordantly, Hypothesis 1a was in the most confirmed by the above findings, while Hypothesis $1 \mathrm{~b}$ was partly confirmed.

\subsection{Effects of Forgiveness, Life Satisfaction and Work Satisfaction on the Estimated Interpersonal Relationships as Best and Worst}

The findings from regression analyses, with life satisfaction, work satisfaction and forgiveness of self, of other and of situations as predictive variables and the employees' perceived as worst or best interpersonal relationship with their colleagues as predicted variable, revealed that the three sets of predictors, in combination, explained a significant amount of the variance of the estimated interpersonal relationships as worst, $\mathrm{R}^{2}=.40, \mathrm{~F}(5,194)=.30 .00, p<.01$, and, mainly of the estimated as best interpersonal relationships, $\mathrm{R}^{2}=.56, \mathrm{~F}(5,194)=67.00, p$ $<.01$.

Additionally, in the group with the best interpersonal relationships, it was found that (a) higher work satisfaction, $\mathrm{b}=.03, \mathrm{t}=3.22, p<.01$, higher life satisfaction, $\mathrm{b}=.08, \mathrm{t}=14.20, p<.01$, higher forgiveness of self, $\mathrm{b}=.15, \mathrm{t}=43.10$, $p<.01$, forgiveness of other, $\mathrm{b}=.03, \mathrm{t}=3.22, p<.01$, and, particularly, forgiveness of situations, $\mathrm{b}=.27, \mathrm{t}=61.00, p<.01$, predicted higher quality of interpersonal relationships. Similarly, in the group with the worst interpersonal relationships, the employees, who were highly satisfied with their work, $\mathrm{b}=.24, \mathrm{t}=$ $5.55, p<.01$, and, who were highly likely to forgive themselves, $\mathrm{b}=.42, \mathrm{t}=15.10$, other, $\mathrm{b}=.03, \mathrm{t}=2.98, p<.01$, and situations, $\mathrm{b}=.46, \mathrm{t}=16.80, p<.01$, estimated as less suffering that relationship, while life satisfaction had no unique effect on it, $\mathrm{b}=.01, \mathrm{t}=1.40, p>.05$.

The above results in the most confirmed Hypotheses $2 \mathrm{a}$ and $2 \mathrm{~b}$, and partly Hypothesis 2c.

\subsection{Effects of Forgiveness, Life Satisfaction and Work Satisfaction on the Attributions for the Interpersonal Relationships}

The results from correlations coefficients analyses (Table 2) and a series of regression analyses (Table 3), with life satisfaction, work satisfaction and forgiveness of self, of other and of situations as predictive variables and each of the attributional dimensions as predicted variable, within each group of interpersonal relationship (best/worst), showed that the three sets of predictors had complementary and positive effects on attributions but their relative power in formulating them varied between best and worst interpersonal relationships and within each of the attributional dimensions. Notably, all the predictors, in combination, proved a more powerful influential factor in the generation of the attributional dimensions for the best interpersonal relationships than for the worst interpersonal relationships, with the exception being in colleague's locus of causality which was better predicted in the worst interpersonal relationships. Similarly, each of the components of forgiveness was more strongly associated with the 
Table 2. Results from correlations coefficients analyses for the associations of employees' life satisfaction, work satisfaction and forgiveness (self, other, situations) with the attributional dimensions for the perceived best and worst interpersonal relationships with their colleagues.

\begin{tabular}{|c|c|c|c|c|c|c|c|c|c|c|}
\hline & \multicolumn{4}{|c|}{ Best interpersonal relationships } & \multicolumn{6}{|c|}{ Worst interpersonal relationships } \\
\hline & 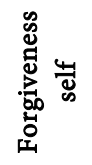 & 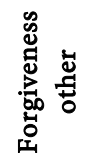 & 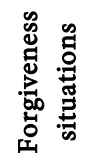 & 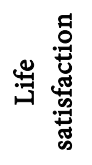 & 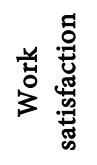 & 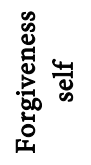 & 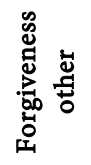 & 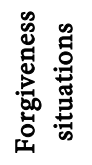 & 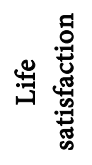 & 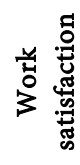 \\
\hline Locus of causality & .19 & -- & .44 & .75 & .64 & .48 & -- & .56 & .24 & .16 \\
\hline Personal controllability & .45 & .41 & .54 & .33 & .21 & .18 & .43 & .38 & .22 & -- \\
\hline Stability & .56 & .44 & .69 & .69 & .62 & .79 & .15 & .85 & .33 & .23 \\
\hline External controllability & .46 & .39 & .61 & .36 & .25 & .37 & .30 & .29 & -- & -- \\
\hline Colleague's locus of causality & .36. & .39 & .43 & .19 & .20 & .30 & .49 & .29 & -- & -- \\
\hline Colleague's personal controllability & .50 & .76 & .44 & -- & -- & .18 & -- & -- & -- & -- \\
\hline Self-colleague locus of causality & .63 & .87 & .57 & .38 & .44 & .32 & .27 & .56 & .27 & -- \\
\hline Self-colleague controllability & .67 & .76 & .74 & .55 & .54 & -- & -- & .21 & .27 & .16 \\
\hline
\end{tabular}

Note: $\mathrm{r}$-values $\leq .18, p<.05 ; \mathrm{r}$-values $>.18, p<.01 ;$-: $\mathrm{r}$-values are not significant at the level of .05 level of significance.

Table 3. Findings from regression analyses for the effects of the employees' life satisfaction, work satisfaction and forgiveness (self, other, situations) on the attributional dimensions for the perceived best and worst interpersonal relationships with their colleagues.

\begin{tabular}{|c|c|c|c|c|c|c|c|c|c|}
\hline & \multirow[t]{2}{*}{ Predictors } & \multicolumn{4}{|c|}{ Best interpersonal relationships } & \multicolumn{4}{|c|}{ Worst interpersonal relationships } \\
\hline & & $\mathbf{R}^{2}$ & $\mathrm{~F}$ & b & $\mathrm{t}$ & $\mathbf{R}^{2}$ & $\mathrm{~F}$ & $\mathrm{~b}$ & $\mathrm{t}$ \\
\hline \multirow[t]{6}{*}{ Locus of causality } & Forgiveness self & & & .19 & 4.35 & & & .15 & 2.50 \\
\hline & Forgiveness other & & & -- & --- & & & -- & --- \\
\hline & Forgiveness situations & & & .32 & 4.97 & & & .41 & 4.85 \\
\hline & Life satisfaction & & & .22 & 2.50 & & & -- & --- \\
\hline & Work satisfaction & & & -- & --- & & & -- & --- \\
\hline & & .62 & 82.90 & & & .33 & 24.50 & & \\
\hline \multirow[t]{6}{*}{ Personal controllability } & Forgiveness self & & & .22 & 3.90 & & & -- & -- \\
\hline & Forgiveness other & & & .10 & 7.35 & & & .15 & 10.00 \\
\hline & Forgiveness situations & & & .40 & 5.00 & & & .53 & 9.45 \\
\hline & Life satisfaction & & & -- & --- & & & -- & --- \\
\hline & Work satisfaction & & & -- & --- & & & -- & --- \\
\hline & & .47 & 34.55 & & & .39 & 41.75 & & \\
\hline \multirow[t]{6}{*}{ Stability } & Forgiveness self & & & .08 & 2.15 & & & .07 & 2.40 \\
\hline & Forgiveness other & & & .07 & 8.87 & & & -- & --- \\
\hline & Forgiveness situations & & & .22 & 4.15 & & & .24 & 7.20 \\
\hline & Life satisfaction & & & .27 & 3.90 & & & -- & \\
\hline & Work satisfaction & & & -- & -- & & & -- & --- \\
\hline & & .78 & 141.98 & & & .75 & 150.50 & & --- \\
\hline
\end{tabular}




\section{Continued}

\begin{tabular}{|c|c|c|c|c|c|c|c|c|c|}
\hline \multirow[t]{6}{*}{ External controllability } & Forgiveness self & & & .66 & 13.15 & & & .27 & 10.05 \\
\hline & Forgiveness other & & & .12 & 11.90 & & & .68 & 16.70 \\
\hline & Forgiveness situations & & & .74 & 14.50 & & & .22 & 6.70 \\
\hline & Life satisfaction & & & .49 & 5.25 & & & -- & --- \\
\hline & Work satisfaction & & & -- & --- & & & -- & --- \\
\hline & & .71 & 97.30 & & & .55 & 63.00 & & \\
\hline \multirow{6}{*}{$\begin{array}{l}\text { Colleague's locus of } \\
\text { causality }\end{array}$} & Forgiveness self & & & .32 & 6.05 & & & .24 & 8.75 \\
\hline & Forgiveness other & & & .08 & 6.48 & & & .14 & 16.00 \\
\hline & Forgiveness situations & & & .52 & 7.00 & & & .15 & 4.50 \\
\hline & Life satisfaction & & & .39 & 4.20 & & & -- & --- \\
\hline & Work satisfaction & & & .19 & 2.48 & & & -- & --- \\
\hline & & .38 & 24.80 & & & .60 & 101.00 & & \\
\hline \multirow{6}{*}{$\begin{array}{l}\text { Colleague's personal } \\
\text { controllability }\end{array}$} & Forgiveness self & & & -- & --- & & & .11 & 8.15 \\
\hline & Forgiveness other & & & .63 & 14.60 & & & -- & --- \\
\hline & Forgiveness situations & & & .43 & 3.55 & & & -- & --- \\
\hline & Life satisfaction & & & -- & --- & & & -- & --- \\
\hline & Work satisfaction & & & -- & --- & & & -- & --- \\
\hline & & .63 & 117.50 & & & .25 & 66.25 & & \\
\hline \multirow{6}{*}{$\begin{array}{l}\text { Self-Colleague locus of } \\
\text { causality }\end{array}$} & Forgiveness self & & & .22 & 23.00 & & & .33 & 9.30 \\
\hline & Forgiveness other & & & .26 & 73.00 & & & .27 & 6.00 \\
\hline & Forgiveness situations & & & .23 & 54.10 & & & .65 & 15.10 \\
\hline & Life satisfaction & & & .33 & 56.75 & & & -- & --- \\
\hline & Work satisfaction & & & -- & --- & & & -- & --- \\
\hline & & .67 & 85.00 & & & .68 & 145.00 & & \\
\hline \multirow{6}{*}{$\begin{array}{l}\text { Self-Colleague } \\
\text { controllability }\end{array}$} & Forgiveness self & & & .11 & 3.65 & & & -- & --- \\
\hline & Forgiveness other & & & .22 & 5.95 & & & -- & --- \\
\hline & Forgiveness situations & & & .30 & 6.80 & & & -- & --- \\
\hline & Life satisfaction & & & .10 & 3.00 & & & .23 & 3.45 \\
\hline & Work satisfaction & & & .13 & 4.00 & & & -- & --- \\
\hline & & .65 & 96.50 & & & .09 & 9.55 & & \\
\hline
\end{tabular}

Note: All F-values are significant at the .01 level of significance; $\mathrm{t}>2.35, p<.01, \mathrm{t} \leq 2.50, \mathrm{p}<.05 ; \mathrm{t}---, p>.05$.

attributions in the best than worst interpersonal relationships, but forgiveness of other, forgiveness of situations and forgiveness of self mainly evidenced link to colleague's controllability, stability and both stability and locus of causality, respectively, for the worst interpersonal relationships.

In addition, the following findings were reported within each group of relationships.

In the group with the best interpersonal relationships of the employees with 
their colleagues, 1) the higher the satisfaction with life, the higher the satisfaction with work and the higher the forgivingness of self, of other and of situations were, the more internal (not association with forgivingness of others), personal controllable, stable, external uncontrollable, internal and personally controllable (not association with satisfaction) to the colleagues, and both controllable and internal to the self-colleague interaction the attributions were, 2) forgivingness of situations, as compared to forgivingness of self and of other, was more strongly related to most of the attributional dimensions except for the dimension of colleague's controllability, and self-colleague locus of causality that were most strongly associated with the forgiveness of others, 3) life satisfaction, in comparison to work satisfaction, was more powerfully associated with the attributions expect for self-colleague locus of causality where the reverse was the case, 4) forgiveness, life satisfaction and work satisfaction, as a group, significantly contributed to the explained variance of the attributional dimensions, $\mathrm{R}^{2}$ ranged from .38 (colleague's locus of causality) to .78 (stability), and 5) forgiveness rather than both life satisfaction and work satisfaction contributed into formulation of the attributions, with work satisfaction being the lowest powerful contributor.

In the group with the worst interpersonal relationships of the employees with their colleagues, 1) higher forgiveness of self, other and situations were associated with higher external (not association with forgivingness of other), personal uncontrollable, unstable, external controllable, external to the colleagues, personally uncontrollable to the colleagues (not association with forgivingness of other and situation), external to self-colleague, and controllable to self-colleague (only association with forgiveness of situation) attributions, 2) the more satisfied they were with their life and their work the more likely to make external, unstable, external uncontrollable and self-colleague uncontrollable attributions, 3) the more satisfied they were with their life the higher the personal uncontrollable and self-colleague uncontrollable the attributions were, 4) forgivingness of situations, of self and of other, as compared to each other, was more powerfully associated with the locus of causality (both self and self-colleague) and stability, external controllability and colleague's controllability, and controllability (both self and self-colleague) respectively, 5) forgiveness, life satisfaction and work satisfaction, as a group, accounted for $9 \%$ (self-colleague controllability) to $75 \%$ (stability) of the observed variation in attributional dimensions and 6) forgiveness of self, of other and of situation evidenced unique contribution in the generation of the attributions, in consistency with the association pattern, while life satisfaction and work satisfaction proved weak predictor of attributions.

Hypotheses $3 \mathrm{a}$ and $3 \mathrm{~b}$ were totally confirmed, while Hypotheses $3 \mathrm{c}, 3 \mathrm{~d}$ and 4 were partly confirmed by the above findings.

\section{Discussion}

This study examined the employees' attributions for their subjectively perceived 
best and worst interpersonal relationships with their colleagues, and addressed the possible impact of dispositional forgiveness (self, other, situations) on the intuitive and attributional appraisals of the same relationships. Additionally, the role of life satisfaction and work satisfaction in the same appraisals was investigated.

\subsection{Attributions for the Colleaguing Interpersonal Relationships}

The findings regarding the scheme of the attributional appraisal of the worker-colleague interpersonal relationships in the most reinforced past empirical evidence and confirmed the research Hypotheses. Employee teachers proved motivated to understand the causes of their interpersonal relationships with their colleagues, by ascribing them to various attributional dimensions (Weiner, 2001, 2014; Wang \& Hall, 2018). Also, colleaguing interpersonal relationships proved very important for the participants as the high variability of the attributions indicates, in consistency with past research which has supported that individuals search for causes to explain the high ego involvement tasks (Argyle, 2001; Wang \& Hall, 2018; Weiner, 2014). Similarly, the attributional pattern within and between the estimated as best and worst interpersonal relationships hinds the working teachers' desire and values of good relationships (Harvey et al., 2005; Karney et al., 2003; Weiner, 2002, 2005, 2010), and complimented previous research which has reported a strong link between attributional processes and relationship satisfaction (Fincham, 2003; Thompson \& Snyder, 1986).

The employees boosted themselves, rose their expectations for a good relationship, multiplied the possibilities of being good the relationship in the future, facilitated relationship engagement and multiplied the longevity of their relationship, by attributing the good interpersonal relationships to stable and personal positive properties along with the self-colleague positive dispositions (Fiedler et al., 1995; Fincham, 2003; Fletcher \& Clark, 2002; Lauermann \& Karabenick, 2013; Rusbult, Arriaga, \& Agnew, 2003; Weiner, 2001). The attributional pattern for the worst colleaguing interpersonal relationships seems not to be complete adaptive. Accurately, although the working teachers protected their ego by making external attributions, attributing the negative relationships to stable factors and to colleague's responsibility, reduced positive expectations, produced the feeling of hopelessness and was likely to lead to learned helplessness, a sense that none effort can lead to good relationship (Fletcher, 2002; Fitness et al., 2005; Peterson \& Steen, 2005; Planalp \& Rivers, 1996; Seligman, 2002; Weiner, 1995, 2001). Further, it seems that the employees had formed expectations for their colleague dispositional behaviour and the content of the interpersonal relationship. Accordantly, teachers implicated stable factors for the best and the worst colleaguing interpersonal relationships that were consistent with their initial expectations, confirming similar past researches (Berscheid \& Ammazalorso, 2003; Bless, 2003; Fincham, 2003; Trope \& Gaunt, 2005; Wang \& Hall, 2018).

Rewarding other studies and Weiner's $(2002,2005)$ interpersonal attribution 
theory, the group of the best interpersonal relationships was discriminated from the group of the worst interpersonal relationships predominately by the attributional dimension of locus of causality. Locus of causality, followed by colleague' controllability, personal controllability and colleague's locus of causality, was the most powerful factor in discriminating the two groups of the employees, while none of the other attributional dimensions further differentiated the two groups. This specific finding probably reflects the workers' tendency of self-focus in identifying themselves as good partners and effective professionals, and their tendency of other-focus in the case of undesirable workplace relations and situations (Macnow, 2019; Williams \& Gilmore, 2008). However, research needs to clarify this speculation.

\subsection{Effects of Forgiveness, Life Satisfaction and Work Satisfaction on the Intuitive and Attributional Appraisals for the Colleaguing Interpersonal Relationships}

Interestingly, forgiving employees used adaptive attribution pattern in explaining their colleaguing relationships, and the working teachers who were highly likely to forgive, compared to working teachers who were low likely to forgive, enjoyed more and suffered less for their best and worst colleaguing interpersonal relationships respectively, supporting previous research evidence documenting the high forgive individuals use optimistic and adaptive reappraisal for a variety of relationships and stressor situations (Hill \& Allemand, 2010; Raj \& Wiltermuth, 2016; Szcześniak \& Soares, 2011; Toussaint \& Friedman, 2009), repair broken relationships with work colleagues and overcome debilitating thoughts and emotions resulting from interpersonal injury (Aquino et al., 2003). Also, forgiveness proved a robust precursor of the intuitive and attributional (except colleague's locus of causality) appraisals for the best than the worst interpersonal relationships, a consistent finding with existent researches reporting the positive correlations of forgiveness with improvement of relationships and its link to greater relationship satisfaction and fewer problems in less troubled relationships (Aquino et al., 2003; Fincham \& Beach, 2007; Fincham, Jackson, \& Beach, 2005; McCullough, 2000; McNulty, 2010). Along similar findings (e.g., McCullough, 2000), this specific finding may also result from contextual variables of colleaguing interpersonal relationships regarding low closeness and commitment (Berscheid \& Ammazzalorso, 2003; McCullough, 2000).

The three components of forgiveness had a significant impact on the appraisals for the best and the worst interpersonal relationships, in consistency with past researches showing that forgiving persons think flexibly (Thompson et al., 2005) and are effective in problem solving and conflict resolution in workplace (Aquino et al., 2001), However, the power of the prediction of forgiveness of self, of other and of situations on the intuitive and the attributional appraisals for the colleaguing interpersonal relationships varied between and within attributional dimensions as well as it varied between and within worst and best interpersonal relationships. This specific finding is an indication that the potential source of 
transgressions "self", "other" and "situations" are unique to conceptualization of forgiveness (Thompson et al., 2005), and highlights the importance of examining the three components of forgiveness. Relative to forgiveness of self and forgiveness of other, forgiveness of situations more strongly influenced the appraisals for colleaguing interpersonal relationships, reinforcing the notion that the predisposition of forgiveness of situation deals adaptively with the different adversities in the working environment, including the interpersonal relationships. Forgiveness of other, as could be expected, most impacted colleague-related attributional dimensions. However, despite these differences, attention should be given to three constructs of forgiveness because neither is more adaptive. Also, investigation needs to verify their relative role in workers' interpersonal relationships-related procedures.

The three components of forgiveness, life satisfaction and work satisfaction, as a group, proved a powerful beneficiary factor to stability than to any other attributional dimension, in both worst and best interpersonal relationships. This specific result seems reasonable thinking that in this study forgiveness is considered as a trait factor, and life satisfaction and work satisfaction is perceived as a cognitive appraisal of an individual's whole life and work respectively.

The pattern of the impact of life satisfaction on the appraisals for the colleaguing relationships is, probably, due to its result from forgivingness, as investigations suggest (Allemand et al., 2012; Kaleta \& Mróz, 2018; Thompson et al., 2005), and due to the high decisive role of forgiveness in the relationships formulation. Accordantly, life satisfaction, in the most had an indirect effect on the appraisals of the relationships through forgiveness. Specifically, life satisfaction was a weak predictor of the generation of the best interpersonal relationships and it did not uniquely impact on the worst interpersonal relationships. Similarly, file satisfaction weakly accounted for unique variance in most of the attributional dimensions in the best interpersonal relationships, and it predicted only self-colleague controllability in the worst interpersonal relationships.

Also, unexpectedly, work satisfaction, perhaps, as it is related to both life satisfaction (Luthans, 2005; Veldman et al., 2013) and dispositional forgiveness (Cox, 2011; Law, 2013), appeared to be weak predictive of the appraisals of the employees' interpersonal relationships with their colleagues, particularly in the worst interpersonal relationships.

\subsection{Limitations, and Implications of the Findings into Colleaguing Interpersonal Relationships and Future Research}

This study constitutes a critical effort towards understanding colleaguing relationships through the examination of the associated cognitive processes and cognition. The attribution pattern underlines that employees' interpersonal relationships with their colleagues constitute a significant aspect of their professional life. Strengthening, then, the positive teacher-colleague relationships beneficiates their happiness and well-being, and the organization itself. Interventions, based on attributional retraining (Seligman, 2002), facilitate to change maladap- 
tive attributional pattern of interpersonal relationships. In line with this, familiarizing the nature and function of the attributions within good/bad interpersonal relationships is essential.

Also, as individual factors influence interpersonal relationships, this investigation included dispositional forgiveness which proved a critical construct to understand how employees develop and appraise interpersonal relationships with their colleagues. High forgiving workers reported adaptive attributional appraisal for their interpersonal relationships. Hence, forgiveness should be addressed by organizational theorists and practicing managers. In doing so, attention should be given to forgiveness of self, of other and of situations. However, it should be mentioned that, although forgiveness had positive impacts on the appraisals for the colleaguing relationships, the question as to whether forgiveness serves a positive overarching outcome seems to be dependent on the closeness of the partners and the context in which the transgression takes place. Future studies need to examine the possible moderating or mediating role of such variables in the link forgiveness-cognitive appraisals of workplace relationships.

In this study, life satisfaction and, particularly, work satisfaction, compared to forgiveness, proved less powerful contributor to cognitive appraisals of interpersonal relationships. Further research is needed to examine the causal directions of the links between forgiveness and relationship cognition and satisfaction.

This study focused on working teacher-colleague interpersonal relationships at one point of time. To better understand these relationships future researches should use longitudinal designs to investigate how they develop, and how the certain cognitive appraisals function in that procedure. Also, while the examined personal factors played an important part in explaining the workplace interpersonal relationships, environmental factors are crucial determinants in the generation of the success or failure of these relationships, and, consequently, should be included in future research.

Nevertheless, this study contributes to and expands the extant research in interpersonal relationships in workplace.

\section{Conflicts of Interest}

The authors declare no conflicts of interest regarding the publication of this paper.

\section{References}

Aldrup, K., Klusmann, U., \& Lüdtke, O. (2017). Does Basic Need Satisfaction Mediate the Link between Stress Exposure and Well-Being? A Diary Study among Beginning Teachers. Learning and Instruction, 50, 21-30. https://doi.org/10.1016/j.learninstruc.2016.11.005

Allemand, M., Hill, P. L., Ghaemmaghami, P., \& Martin, M. (2012). Forgivingness and Subjective Well-Being in Adulthood: The Moderating Role of Future Time Perspective. Journal of Research in Personality, 46, 32-39. https://doi.org/10.1016/j.jrp.2011.11.004

Aquino, K., Grover, S.L., Goldman, B., \& Folger, R. (2003). When Push Doesn't Come to Shove. Journal of Management Inquiry, 12, 209-216.

https://doi.org/10.1177/1056492603256337 
Aquino, K., Tripp, T. M., \& Bies, R. J. (2001). How Employees Respond to Personal Offense: The Effects of Blame Attribution, Victim Status, and Offender Status on Revenge and Reconciliation in the Workplace. Journal of Applied Psychology, 86, 52-59. https://doi.org/10.1037/0021-9010.86.1.52

Argyle, M. (2001). Social Relationships. In M. Hewstone, W. Stroebe, J. P. Codol, \& G. M. Stepheson (Eds.), Introduction to Social Psychology (pp. 222-245). Oxford: Blackwell.

Aspinwall, L. G., \& Staudinger, U. M. (2003). A Psychology of Human Strengths: Some Central Issues of an Emerging Field. In L. G. Aspinwall, \& U. M. Staudinger (Eds.), $A$ Psychology of Human Strengths: Fundamental Questions and Future Directions for a Positive Psychology (pp. 9-22). San Francisco, CA: Berrett-Koehler Publishers Inc. https://doi.org/10.1037/10566-001

Ayten, A., \& Ferhan, H. (2016). Forgiveness, Religiousness, and Life Satisfaction: An Empirical Study on Turkish and Jordanian University Students. Spiritual Psychology and Counseling, 1, 75-84. https://doi.org/10.12738/spc.2016.1.0006

Balliet, D. (2010). Conscientiousness and Forgivingness: A Meta-Analysis. Personality and Individual Differences, 48, 259-263. https://doi.org/10.1016/j.paid.2009.10.021

Bell, C. A., Kamble, S. V., \& Fincham, F. D. (2018) Forgiveness, Attributions, and Marital Quality in U.S. and Indian Marriages. Journal of Couple \& Relationship Therapy, 17, 276-293. https://doi.org/10.1080/15332691.2018.1433569

Berndsen, M., \& Manstead, A. S. R. (2007). On the Relationship between Responsibility and Guilt: Antecedent Appraisal or Elaborated Appraisal? European Journal of Social Psychology, 37, 774-792. https://doi.org/10.1002/ejsp.397

Berry, J. W., \& Worthington, E. L. J. (2001). Forgivingness, Relationship Quality, Stress While Imagining Relationship Events, and Physical and Mental Health. Journal of Counseling Psychology, 48, 447-455. https://doi.org/10.1037/0022-0167.48.4.447

Berry, J. W., Worthington, E. L., Parrott, L., O’Connor, L. E., \& Wade, N. G. (2001). Dispositional Forgivingness: Development and Construct Validity of the Transgression Narrative Test of Forgivingness (TNTF). Personality and Social Psychology Bulletin, 27, 1277-1290. https://doi.org/10.1177/01461672012710004

Berscheid, E., \& Ammazzalorso, H. (2003). Emotional Experience in Close Relationships. In G. J. O. Fletcher, \& M. S. Clark (Eds.), Handbook of Social Psychology: Interpersonal Processes (pp. 308-330). Oxford: Blackwell. https://doi.org/10.1002/9780470998557.ch12

Bérubé, N., Donia, M., Gagné, M., Houlfort, N., \& Koestner, R. (2007). Validation of the Satisfaction with Work Scale. ASAC, 28, 270-279.

Bérubé, N., Donia, M., Gagné, M., Houlfort, N., \& Lvina, E. (2016). Validation Evidence for the Work Domain Satisfaction Scale in Two Languages. International Journal of Psychological Studies, 8, 26-39. https://doi.org/10.5539/ijps.v8n3p26

Bies, R. J., \& Tripp, T. M. (1997). Revenge in Organizations: The Good, the Bad, and the Ugly. In R. W. Griffin, A. O’Leary-Kelly, \& J. Collins (Eds.), Dysfunctional Behavior in Organizations: Vol. 1. Violent Behaviors in Organizations (pp. 49-67). Greenwich, CT: JAI.

Blascovich, J., \& Mandes, W. B. (2000). Challenge and Threat Appraisals: The Role of Affective Cues. In J. P. Forgas (Ed.), Feeling and Thinking: The Role of Affect in Social Cognition (pp. 131-152). New York: Cambridge University Press.

Bless, H. (2003). The Consequences of Mood on the Processing of Social Information. In A. Tesser, \& N. Schwarz (Eds.), Handbook of Social Psychology: Intraindividual Processes (pp. 391-412). Oxford: Blackwell.

https://doi.org/10.1111/b.9780631210344.2002.00020.x 
Boonyarit, I., Chuawanleeb, W., Macaskillc, A., \& Supparerkchaisakul, N. (2013). A Psychometric Analysis of the Workplace Forgiveness Scale. Europe's Journal of Psychology, 9, 319-338. https://doi.org/10.5964/ejop.v9i2.551

Bradfield, M. O., \& Aquino, K. (1999). The Effects of Blame Attributions and Offender Likableness on Revenge and Forgiveness in the Workplace. Journal of Management, 25, 607-631. https://doi.org/10.1177/014920639902500501

Brose, L. A., Rye, M. S., Lutz-Zois, C., \& Ross, S. R. (2005). Forgiveness and Personality Traits. Personality and Individual Differences, 39, 35-46. https://doi.org/10.1016/j.paid.2004.11.001

Buss, D. (2005). The Handbook of Evolutionary Psychology. Hoboken, NJ: Wiley.

Butler, D. S., \& Mullis, F. (2001). Forgiveness: A Conflict Resolution Strategy in the Workplace. The Journal of Individual Psychology, 57, 259-272.

Cameron, K., \& Caza, A. (2002). Organizational and Leadership Virtues and the Role of Forgiveness. Journal of Leadership \& Organizational Studies, 9, 33-48. https://doi.org/10.1177/107179190200900103

Cano-García, F. J., Padilla-Muñoz, E. M., \& Carrasco-Ortiz, M. Á. (2005). Personality and Contextual Variables in Teacher Burnout. Personality and Individual Differences, 38, 929-940. https://doi.org/10.1016/j.paid.2004.06.018

Claessens, L. C. A., Van Tartwijk, J., Van der Want, A. C., Pennings, H. J. M., Verloop, N., Den Brok, P. J., \& Wubbels, T. (2017). Positive Teacher-Student Relationships Go beyond the Classroom, Problematic Ones Stay Inside. The Journal of Educational Research, 110, 478-493. https://doi.org/10.1080/00220671.2015.1129595

Collins, N. L., Ford, M. B., Guichard, A. C., \& Allard, L. M. (2006). Working Models of Attachment and Attribution Processes in Intimate Relationships. Personality and Social Psychology Bulletin, 32, 201-219. https://doi.org/10.1177/0146167205280907

Cox, S. S. (2011). An Investigation of Forgiveness Climate and Workplace Outcomes. Academy of Management Proceedings, 2011, 1-6. https://doi.org/10.5465/ambpp.2011.65869629

Deci, E. L., \& Ryan, R. M. (2000). The "What" and "Why" of Goal Pursuits: Human Needs and the Self-Determination of Behavior. Psychological Inquiry, 11, 227-268. https://doi.org/10.1207/S15327965PLI1104_01

Demir, M. (2008). Sweetheart, You Really Make Me Happy: Romantic Relationship Quality and Personality as Predictors of Happiness among Emerging Adults. Journal of Happiness Studies, 9, 257-277. https://doi.org/10.1007/s10902-007-9051-8

Di Fabio, A., \& Kenny, E. M. (2016). From Decent Work to Decent Lives: Positive Self and Relational Management (PS\&RM) in the 21st Century. Frontier Psychology, 7, 361. https://doi.org/10.3389/fpsyg.2016.00361

Diener, E. (1994). Assessing Subjective Well-Being: Progress and Opportunities. Social Indicators Research, 31, 103-157. https://doi.org/10.1007/BF01207052

Diener, E. (2000). Subjective Well-Being. The Science of Happiness and a Proposal for National Index. American Psychologist, 55, 34-43. https://doi.org/10.1037/0003-066X.55.1.34

Diener, E. D., Emmons, R. A., Larsen, R. J., \& Griffin, S. (1985). The Satisfaction with Life Scale. Journal of Personality Assessment, 49, 71-75. https://doi.org/10.1207/s15327752jpa4901_13

Diener, E., \& Seligman, M. (2002). Very Happy People. Psychological Science, 13, 81-84. https://doi.org/10.1111/1467-9280.00415

Diener, E., \& Tay, L. (2012). A Scientific Review of the Remarkable Benefits of Happiness 
for Successful and Healthy Living. Report of the Well-Being Working Group, Royal Government of Bhutan: Report to the United Nations General Assembly, Well-Being and Happiness: A New Development Paradigm, UN, NY.

Diener, E., Inglehart, R., \& Tay, L. (2013). Theory and Validity of Life Satisfaction Scales. Social Indicators Research, 112, 497-527. https://doi.org/10.1007/s11205-012-0076-y

Diener, E., Lucas, R. E., \& Oishi, S. (2005). Subjective Well-Being: The Science of Happiness and Life Satisfaction. In C. R. Snyder, \& S. J. Lopez (Eds.), Handbook of Positive Psychology (pp. 63-73). Oxford: University Press.

Dix, T. H., \& Grusec, J. E. (1985). Parent Attribution Processes in the Socialization of Children. In I. E. Siegel (Ed.), Parental Belief Systems: The Psychological Consequences for Children (pp. 177-199). Hillsdale, NJ: Erlbaum.

Erber, R., \& Gilmour, R. (1995). Theoretical Frameworks for Personal Relationships. Hillsdale, NJ: Lawrence Erlbaum.

Erdogan, B., Bauer, T. N., Truxillo, D. M., \& Mansfield, L. R. (2012). Whistle While You Work: A Review of the Life Satisfaction Literature. Journal of Management, 38, 1038-1083. https://doi.org/10.1177/0149206311429379

Fehr, R., Gelfand, M. J., \& Nag, M. (2010). The Road to Forgiveness: A Meta-Analytic Synthesis of Its Situational and Dispositional Correlates. Psychological Bulletin, 136, 894-914. https://doi.org/10.1037/a0019993

Fiedler, K., Semin, G. R., Finkenauer, D., \& Berkel, I. (1995). Actor-Observer Bias in Close Relationships. Personality and Social Psychology Bulletin, 21, 525-538. https://doi.org/10.1177/0146167295215010

Fincham, F. D. (1985). Attribution Processes in Distressed and Nondistressed Couples: II. Responsibility for Marital Problems. Journal of Abnormal Psychology, 94, 183-190. https://doi.org/10.1037/0021-843X.94.2.183

Fincham, F. D. (2001). Attributions and Close Relationships: From Balkanization to Integration. In G. J. Fletcher, \& M. Clark (Eds.), Blackwell Handbook of Social Psychology (pp. 3-31). Oxford: Blackwell.

Fincham, F. D. (2003). Attributions in Close Relationships: From Balkanization to Integration. In G. J. O. Fletcher, \& M. S. Clark (Eds.), Handbook of Social Psychology: Interpersonal Processes (pp. 3-31). Oxford: Blackwell.

Fincham, F. D., Beach, S. R. H., \& Davila, J. (2004). Forgiveness and Conflict Resolution in Marriage. Journal of Family Psychology, 18, 72-81. https://doi.org/10.1037/0893-3200.18.1.72

Fincham, F. D., Jackson, H., \& Beach, S. R. H. (2005). Transgression Severity and Forgiveness: Different Moderators for Objective and Subjective Severity. Journal of Social and Clinical Psychology, 24, 860-875. https://doi.org/10.1521/jscp.2005.24.6.860

Fincham, F. D., Paleari, G., \& Regalia, C. (2002). Forgiveness in Marriage: The Role of Relationship Quality, Attributions and Empathy. Personal Relationships, 9, 27-37. https://doi.org/10.1111/1475-6811.00002

Fincham, F. D., Rogge, R., \& Beach, S. R. H. (2018). Relationship Satisfaction. In A. L. Vangelisti \& D. Perlman (Eds.), The Cambridge Handbook of Personal Relationships (pp. 422-436). Cambridge: Cambridge University Press.

https://doi.org/10.1017/9781316417867.033

Fincham, F., \& Beach, S. R. H. (2007). Forgiveness and Marital Quality: Precursor or Consequence in Well-Established Relationships? The Journal of Positive Psychology, 2, 260-268. https://doi.org/10.1080/17439760701552360

Fitness, J., Fletcher, G. J. O., \& Overall, N. (2005). Interpersonal Attraction and Intimate 
Relationships. In M. A. Hogg, \& J. Cooper (Eds.), Handbook of Social Psychology (pp. 258-278). London: Sage.

Fletcher, G. J. O. (2002). The New Science of Intimate Relationships. Oxford: Basil Blackwell. https://doi.org/10.1002/9780470773390

Fletcher, G. J. O., \& Clark, M. S. (2002). Handbook of Social Psychology: Interpersonal Processes. Oxford: Basil Blackwell. https://doi.org/10.1111/b.9780631212294.2002.00001.x

Fletcher, G. J. O., \& Thomas, G. (1996). Close Relationship Lay Theories: Their Structure and Function. In G. J. O. Fletcher, \& J. Fitness (Eds.), Knowledge Structures in Close Relationships: A Social Psychological Approach (pp. 3-24). Hillsdale, NJ: Lawrence Erlbaum.

Fletcher, G. J. O., \& Thomas, G. (2000). Behavior and On-Line Cognition in Marital Interaction. Personal Relationships, 7, 111-130. https://doi.org/10.1111/j.1475-6811.2000.tb00007.x

Fletcher, G. J. O., Fitness, J., \& Blampied, N. M. (1990). The Link between Attributions and Happiness in Close Relationships: The Role of Depression and Explanatory Style. Journal of Social and Clinical Psychology, 9, 243-255.

https://doi.org/10.1521/jscp.1990.9.2.243

Freedman, S. R., \& Enright, R. D. (1996). Forgiveness as an Intervention Goal with Incest Survivors. Journal of Consulting and Clinical Psychology, 64, 510-517. https://doi.org/10.1037/0022-006X.64.5.983

Freedman, S., \& Zarifkar, T. (2016). The Psychology of Interpersonal Forgiveness and Guidelines for Forgiveness Therapy: What Therapists Need to Know to Help Their Clients Forgive. Spirituality in Clinical Practice, 3, 45-58. https://doi.org/10.1037/scp0000087

Friedman, I. A. (2000). Burnout in Teachers: Shattered Dreams of Impeccable Professional Performance. Journal of Clinical Psychology, 56, 595-606. https://doi.org/10.1002/(SICI)1097-4679(200005)56:5<595::AID-JCLP2>3.0.CO;2-Q

Friedman, I. A. (2006). Classroom Management and Teacher Stress and Burnout. In C. M. Evertson, \& C. S. Weinstein (Eds.), Handbook of Classroom Management: Research, Practice, and Contemporary Issues (pp. 925-944). Mahwah, NJ: Erlbaum.

Friesen, M. D., Fletcher, G. J. O., \& Overall, N. C. (2005). A Dyadic Assessment of Forgiveness in Intimate Relationships. Personal Relationships, 12, 61-77. https://doi.org/10.1111/j.1350-4126.2005.00102.x

Gagne, F. M. (2018). From Strategy to Action: Transforming Organizational Goals into Organizational Behavior. International Journal of Management Reviews, 20, 83-104. https://doi.org/10.1111/ijmr.12159

Gagné, F. M., \& Lydon, J. E. (2004). Bias and Accuracy in Close Relationships: An Integrative Review. Personality and Social Psychology Review, 8, 322-338. https://doi.org/10.1207/s15327957pspr0804_1

Gavish, B., \& Friedman, I. A. (2010). Novice Teacher's Experience of Teaching: A Dynamic Aspect of Burnout. Social Psychology of Education, 13, 141-167.

https://doi.org/10.1007/s11218-009-9108-0

Gersten, R. (2001). Sorting Out the Roles of Research in the Improvement of Practice. Learning Disabilities Research \& Practice, 16, 45-50. https://doi.org/10.1111/0938-8982.00005

Ghenghesh, P. (2013). Job Satisfaction and Motivation-What Makes Teachers Tick? British Journal of Education, Society \& Behavioural Science, 3, 456-466. 
https://doi.org/10.9734/BJESBS/2013/5156

Gilbert, D. T., \& Malone, P. S. (1995). The Correspondence Bias: The What, When, How and Why of Unwarranted Dispositional Inference. Psychological Bulletin, 111, 21-38. https://doi.org/10.1037/0033-2909.117.1.21

Gottman, J. M. (1994). What Predicts Divorce? Hillsdale, NJ: Erlbaum.

Greitemeyer, T., \& Weiner, B. (2003). Asymmetrical Attributions for Approach versus Avoidance Behavior. Personality and Social Psychology Bulletin, 29, 1371-1382. https://doi.org/10.1177/0146167203255766

Guchait, P., Madera, J., \& Dawson, M. (2016). Learning in the Service Environment: The Influence of Diversity Climate. Journal of Service Theory and Practice, 26, 448-470. https://doi.org/10.1108/JSTP-04-2015-0096

Hall, J. H., \& Fincham, F. D. (2005). Self-Forgiveness: The Stepchild of Forgiveness Research. Journal of Social and Clinical Psychology, 24, 621-637. https://doi.org/10.1521/jscp.2005.24.5.621

Hall, J. H., \& Fincham, F. D. (2006). Relationship Dissolution Following Infidelity: The Roles of Attributions and Forgiveness. Journal of Social and Clinical Psychology, 25, 508-522. https://doi.org/10.1521/jscp.2006.25.5.508

Hargreaves, A. (2000). Mixed Emotions: Teachers' Perceptions of Their Interactions with Students. Teaching and Teacher Education, 16, 811-826.

https://doi.org/10.1016/S0742-051X(00)00028-7

Harvey, J. H. (1987). Attributions in Close Relationships: Research and Theoretical Development. Journal of Social and Clinical Psychology, 5, 8-20. https://doi.org/10.1521/jscp.1987.5.1.8

Harvey, J. H., \& Omarzu, J. (1999). Minding the Close Relationship. Personality and Social Psychology Review, 1, 223-239. https://doi.org/10.1017/CBO9780511527845

Harvey, J., Pauwels, B., \& Zickmund, S. (2005). Relationship Connections: The Role of Minding in the Enhancement of Closeness. In C. R. Snyder, \& S. Lopez (Eds.), Handbook of Positive Psychology (pp. 423-434). Oxford: University Press.

Heller, D., Judge, T., \& Watson, D. (2002). The Confounding Role of Personality and Trait Affectivity in the Relationship between Job and Life Satisfaction. Journal of Organizational Behavior, 23, 815-835. https://doi.org/10.1002/job.168

Helliwell, J. F., Layard, R., \& Sachs, J. (2013). World Happiness Report. New York: Earth Institute, Columbia University.

Hewstone, M., \& Antaki, M. (2001). Attribution Theory and Social Explanations. In M. Hewstone, W. Stroebe, J. P. Codol, \& G. M. Stepheson (Eds.), Introduction to Social Psychology (pp. 111-141). Oxford: Basil Blackwell.

Hill, P. L., \& Allemand, M. (2010). Forgivingness and Adult Patterns of Individual Differences in Environmental Mastery and Personal Growth. Journal of Research in Personality, 44, 245-250. https://doi.org/10.1016/j.jrp.2010.01.006

Hombrados-Mendieta, I., \& Cosano-Rivas, F. (2013). Burnout, Workplace Support, Job Satisfaction and Life Satisfaction among Social Workers in Spain: A Structural Equation Model. International Social Work, 56, 228-246.

https://doi.org/10.1177/0020872811421620

Irving, P. G., \& Monte, S. D. (2009). Met Expectations: The Effects of Expected and Delivered Inducements on Employee Satisfaction. Journal of Occupational and Organizational Psychology, 82, 431-451. https://doi.org/10.1348/096317908X312650

Iwai, T., \& Carvalho, J. V. D. F. (2020). Can a Leopard Change Its Spots? The Effects of Implicit Theories of Personality on Forgiveness via Attributions of Behavioral Stability. 
Personality and Individual Differences, 157, Article No. 109800.

https://doi.org/10.1016/j.paid.2019.109800

Judge, T. A., \& Bono, J. E. (2001). Relationship of Core Self-Evaluations Traits-Self-Esteem, Generalized Self-Efficacy, Locus of Control, and Emotional Stability-With Job Satisfaction and Job Performance: A Meta-Analysis. Journal of Applied Psychology, 86, 80-92. https://doi.org/10.1037/0021-9010.86.1.80

Kaleta, K., \& Mróz, J. (2018). Forgiveness and Life Satisfaction across Different Age Groups in Adults. Personality and Individual Differences 120, 17-23. https://doi.org/10.1016/j.paid.2017.08.008

Kalish, Y., \& Robins, G. (2006). Psychological Predispositions and Network Structure: The Relationship between Individual Predispositions, Structural Holes and Network Closure. Social Networks, 28, 56-84. https://doi.org/10.1016/j.socnet.2005.04.004

Karney, B. R., McNulty, J. K., \& Bradbury, T. N. (2003). Cognition and the Development of Close Relationships. In G. J. O. Fletcher, \& M. S. Clark (Eds.), Handbook of Social Psychology: Interpersonal Processes (pp. 32-59). Oxford: Blackwell. https://doi.org/10.1002/9780470998557.ch2

Klassen, R. M., \& Chiu, M. M. (2010). Effects on Teachers' Self-Efficacy and Job Satisfaction: Teacher Gender, Years of Experience, and Job Stress. American Psychological Association, 102, 741-756. https://doi.org/10.1037/a0019237

Kyriacou, C. (2001). Teacher Stress: Directions for Future Research. Educational Review, 53, 27-35. https://doi.org/10.1080/00131910120033628

Lauermann, F., \& Karabenick, S. A. (2013). The Meaning and Measure of Teachers' Sense of Responsibility for Educational Outcomes. Teaching and Teacher Education, 30, 13-26. https://doi.org/10.1016/j.tate.2012.10.001

Law, M. (2013). Exploring Forgiveness: Do Benevolence and Revenge Associate with Procedural Justice, Workplace Satisfaction and Intention to Leave? International Journal of Management Sciences and Business Research, 2, 167-179.

Lawler-Row, K. A., \& Piferi, R. L. (2006). The Forgiving Personality: Describing a Life Well Lived? Personality and Individual Differences, 41, 1009-1020. https://doi.org/10.1016/j.paid.2006.04.007

Lawler-Row, K. A., Younger, J. W., Piferi, R. L., Jobe, R. L., Edmondson, K. A., \& Jones, W. H. (2005). The Unique Effects of Forgiveness on Health: An Exploration of Pathways. Journal of Behavioral Medicine, 28, 157-167. https://doi.org/10.1007/s10865-005-3665-2

Leary, M. R. (2000). Affect, Cognition and the Social Emotions. In J. P. Forgas (Ed.), Feeling and Thinking: The Role of Affect in Social Cognition (pp. 331-356). Cambridge: University Press.

Lichtenfeld, S., Maier, M. A., Buechner, V. L., \& Fernández-Capo, M. (2019). The Influence of Decisional Land Emotional Forgiveness on Attributions. Frontiers in Psychology, 10, Article 1425. https://doi.org/10.3389/fpsyg.2019.01425

Lucas, R. E., Dyrenforth, P. S., \& Diener, E. (2008). Four Myths about Subjective Well-Being. Social and Personality Psychology Compass, 2, 2001-2015.

https://doi.org/10.1111/j.1751-9004.2008.00140.x

Luhmann, M., Hofmann, W., Eid, M., \& Lucas, R. E. (2012). Subjective Well-Being and Adaptation to Life Events: A Meta-Analysis. Journal of Personality and Social Psychology, 102, 592-615. https://doi.org/10.1037/a0025948

Luthans, F. (2005). Organizational Behavior (10th ed.). Boston, MA: McGraw Hill.

Macnow, A. S. (2019). MCAT Behavioral Sciences Review 2018-2019. New York: Kaplan. 
Mafini, C., \& Pooe, D. R. (2013). The Relationship between Employee Satisfaction and Organizational Performance: Evidence from a South African Government Department. SA Journal of Industrial Psychology, 39, 49-58. https://doi.org/10.4102/sajip.v39i1.1090

Martin, A. J. (2014). Interpersonal Relationships and Students' Academic and Non-Academic Development: What Outcomes Peers, Parents, and Teachers Do and Do Not Impact. In D. Zandvliet, P. den Brok, T. Mainhard, \& J. Tartwijk (Eds.), Interpersonal Relationships in Education: From Theory to Practice (pp. 9-24). Rotterdam: Sense. https://doi.org/10.1007/978-94-6209-701-8_2

Martin, A. J., \& Collie, R. J. (2019). Teacher-Student Relationships and Students' Engagement in High School: Does the Number of Negative and Positive Relationships with Teachers Matter? Journal of Educational Psychology, 111, 861-876. https://doi.org/10.1037/edu0000317

McAuley, E., Duncan, T. E., \& Russell, D. W. (1992). Measuring Causal Attributions: The Revised Causal Dimension Scale (CDSII). Personality and Social Psychology Bulletin, 18, 566-573. https://doi.org/10.1177/0146167292185006

McCullough, M. E. (2000). Forgiveness as Human Strength: Theory, Measurement, and Links to Well-Being. Journal of Social and Clinical Psychology, 19, 43-55. https://doi.org/10.1521/jscp.2000.19.1.43

McCullough, M. E., Fincham, F. D., \& Tsang, J. (2003). Forgiveness, Forbearance, and Time: The Temporal Unfolding of Transgression-Related Interpersonal Motivations. Journal of Personality and Social Psychology, 84, 540-557. https://doi.org/10.1037/0022-3514.84.3.540

McNulty, J. K. (2010). When Positive Processes Hurt Relationships. Current Directions in Psychological Science, 19, 167-171. https://doi.org/10.1177/0963721410370298

Moolenaar, N. M., Daly, A. J., Sleegers, P. J. C., \& Karsten, S. (2014). Social Forces in School Teams: How Demographic Composition Affects Social Relationships. In D. Zandvliet, P. den Brok, T. Mainhard, \& J. Tartwijk (Eds.), Interpersonal Relationships in Education: From Theory to Practice (pp. 159-181). Rotterdam: Sense. https://doi.org/10.1007/978-94-6209-701-8_10

Mount, M., Ilies, R., \& Johnson, E. (2006). Relationship of Personality Traits and Counterproductive Work Behaviors: The Mediating Effects of Job Satisfaction. Personnel Psychology, 59, 591-622. https://doi.org/10.1111/j.1744-6570.2006.00048.x

Mróz, J., \& Kaleta, K. (2019). The Moderating Role of Forgiveness in the Relationship between Work Engagement and Job Satisfaction. Annales Universitatis Mariae Curie, Annales Universitatis Mariae Curie-Skłodowska, 32, 179-195.

https://doi.org/10.17951/j.2019.32.4.179-195

Pennings, H. J. M., Brekelmans, M., Sadler, P., Claessens, L. C. A., van der Want, A. C., \& van Tartwijk, J. (2018). Interpersonal Adaptation in Teacher-Student Interaction. Learning and Instruction, 55, 41-57. https://doi.org/10.1016/j.learninstruc.2017.09.005

Peterson, C., \& Steen, T. A. (2005). Optimistic Explanatory Style. In C. R. Snyder, \& S. J. Lopez (Eds.), Handbook of Positive Psychology (pp. 244-256). Oxford: University Press.

Planalp, S., \& Rivers, M. (1996). Changes in Knowledge of Personal Relationships. In G. J. O. Fletcher, \& J. Fitness (Eds.), Knowledge Structures in Close Relationships: A Social Psychological Approach (pp. 299-324). Hillsdale, NJ: Lawrence Erlbaum.

Raj, M., \& Wiltermuth, S. S. (2016). Barriers to Forgiveness. Social and Personality Psychology Compass, 10, 679-690. https://doi.org/10.1111/spc3.12290

Reed, G. L., \& Enright, R. D. (2006). The Effects of Forgiveness Therapy on Depression, Anxiety, and Posttraumatic Stress for Women after Spousal Emotional Abuse. Journal of Consulting and Clinical Psychology, 74, 920-929. 
https://doi.org/10.1037/0022-006X.74.5.920

Reeve, J., \& Su, Y. (2014). Teacher Motivation. In M. Gagne (Ed.), The Oxford Handbook of Work Engagement, Motivation, and Self-Determination (pp. 349-362). Oxford: Oxford University press.

Roberts, R. C. (1995). Forgivingness. American Philosophical Quarterly, 32, 289-306.

Rogge, R. D., Fincham, F. D., Crasta, D., \& Maniaci, M. R. (2017). Positive and Negative Evaluation of Relationships: Development and Validation of the Positive-Negative Relationship Quality (PN-RQ) Scale. Psychological Assessment, 29, 1028-1043. https://doi.org/10.1037/pas0000392

Rusbult, C. E., Arriaga, X. B., \& Agnew, C. R. (2003). Interdependence in Close Relationships. In G. J. O. Fletcher, \& M. S. Clark (Eds.), Handbook of Social Psychology: Interpersonal Processes (pp. 359-387). Oxford: Blackwell.

Rye, M. S., \& Pargament, K. I. (2002). Forgiveness and Romantic Relationships in College: Can It Heal the Wounded Heart? Journal of Clinical Psychology, 58, 419-441. https://doi.org/10.1002/jclp.1153

Rye, M. S., Loaicono, D. M., Folck, C. D., Olszewski, B. T., Heim, T. A., \& Madia, B. P. (2001). Evaluation of the Psychometric Properties of Two Forgiveness Scales. Current Psychology, 20, 260-277. https://doi.org/10.1007/s12144-001-1011-6

Saphire-Bernstein, S., \& Taylor, S. E. (2013). Close Relationships and Happiness. In L. Boniwell, S. A. David, \& A. C. Ayers (Eds.), Oxford Handbook of Happiness (pp. 821-833). Oxford: Oxford University Press. https://doi.org/10.1093/oxfordhb/9780199557257.013.0060

Schoebi, D., \& Randall, A. K. (2015). Emotional Dynamics in Intimate Relationships. Emotion Review, 7, 342-348. https://doi.org/10.1177/1754073915590620

Schunk, D. H., \& Zimmerman, B. J. (2006). Competence and Control Beliefs: Distinguishing the Means and Ends. In P. A. Alexander, \& P. H. Winne (Eds.), Handbook of Educational Psychology (pp. 349-367). Hillsdale, NJ: Lawrence Erlbaum Associates Publishers.

Seligman, M. E. P. (2002). Authentic Happiness: Using the New Positive Psychology to Realise Your Potential for Lasting Fulfilment. New York: Free Press.

Seligman, M. E. P. (2005). Positive Psychology, Positive Prevention, and Positive Therapy. In C. R. Snyder, \& S. J. Lopez (Eds.), Handbook of Positive Psychology (pp. 3-9). Oxford: University Press.

Siemer, M., Mauss, I., \& Gross, J. (2007). Same Situation-Different Emotions: How Appraisals Shape Our Emotions. Emotion, 7, 592-600.

https://doi.org/10.1037/1528-3542.7.3.592

Singh, K., \& Billingsley, B. (1996). Intent to Stay in Teaching: Teachers of Students with Emotional Disorders versus Other Special Educators. Remedial and Special Education, 17, 37-47. https://doi.org/10.1177/074193259601700105

Skaalvik, E. M., \& Skaalvik, S. (2011). Teacher Job Satisfaction and Motivation to Leave the Teaching Profession: Relations with School Context, Feeling of Belonging, and Emotional Exhaustion. Teaching and Teacher Education, 27, 1029-1038.

https://doi.org/10.1016/j.tate.2011.04.001

Skarlicki, D. P., \& Folger, R. (1997). Retaliation in the Workplace: The Roles of Distributive, Procedural, and Interactional Justice. Journal of Applied Psychology, 82, 434-443. https://doi.org/10.1037/0021-9010.82.3.434

Smith, C. A., \& Lazarus, R. S. (1990). Emotions and Adaptation. In L. A. Pervin (Ed.), Handbook of Personality: Theory and Research (pp. 609-637). New York: Guilford. 
Stephanou, G. (2005). Academic Performance and Interpersonal Relationships. In F. Vlachos, F. Bonoti, P. Metallidou, I. Dermitzaki, \& A. Efklides (Eds.), Human Behavior and Learning. Scientific Annals of the Psychological Society of Northern Greece (Vol. 3, pp. 201-228). Athens: Ellinika Grammata. (In Greek)

Stephanou, G. (2011). Children Friendship: The Role of Hope in Attributions, Emotions and Expectations. Psychology, 2, 875-888. https://doi.org/10.4236/psych.2011.28133

Stephanou, G. (2012). Romantic Relationships in Emerging Adulthood: Perception-Partner Ideal Discrepancies, Attributions, and Expectations. Psychology, 3, 150-160. https://doi.org/10.4236/psych.2012.32023

Stephanou, G., \& Athanasiadou, K. (2020). Interpersonal Relationships: Cognitive Appraisals, Emotions and Hope. European Journal of Psychology and Educational Research, 3, 13-38. https://doi.org/10.12973/ejper.3.1.13

Stephanou, G., Gkavras, G., \& Doulkeridou, M. (2013). The Role of Teachers' Self- and Collective-Efficacy Beliefs on Their Job Satisfaction and Experienced Emotions in School. Psychology, 4, 268-278. https://doi.org/10.4236/psych.2013.43A040

Stone, M. (2002). Forgiveness in the Workplace. Industrial and Commercial Training, 34, 278-286. https://doi.org/10.1108/00197850210447282

Swaminathan, S., \& Jawahar, P. D. (2013). Job Satisfaction as a Predictor of Organizational Citizenship Behavior: An Empirical Study. Global Journal of Business Research, 7, 71-80.

Szcześniak, M., \& Soares, E. (2011). Are Proneness to Forgive, Optimism and Gratitude Associated with Life Satisfaction? Polish Psychological Bulletin, 42, 20-23. https://doi.org/10.2478/v10059-011-0004-z

Szostek, D. (2019). The Impact of the Quality of Interpersonal Relationships between Employees on Counterproductive Work Behavior: A Study of Employees in Poland. Sustainability, 11, 5916. https://doi.org/10.3390/su11215916

Thompson, J. S., \& Snyder, D. K. (1986). Attribution Theory in Intimate Relationships: A Methodological Review. American Journal of Family Therapy, 14, 123-138. https://doi.org/10.1080/01926188608250629

Thompson, L. Y., \& Shahen, P. E. (2003). Forgiveness in the Workplace. In R. A. Giacalone, \& C. L. Jurkiewicz (Eds.), Handbook of Workplace Spirituality and Organizational Performance (pp. 405-420). New York, London: Me Sharpe.

Thompson, L. Y., Snyder, C. R., Hoffman, L., Michael, S. T., Rasmussen, H. N., Roberts, D. E. et al. (2005). Dispositional Forgiveness of Self, Others, and Situations. Journal of Personality, 73, 313-359. https://doi.org/10.1111/j.1467-6494.2005.00311.x

Thoresen, C. E., Harris, A. H., \& Luskin, F. (2000). Forgiveness and Health: An Unanswered Question. In M. E. McCullough, K. I. Pargament, \& C. E. Thoresen (Eds.), Forgiveness: Theory, Research, and Practice (pp. 254-280). New York: Guilford Press.

Timmermans, T., Van Mechelen, I., \& Kuppens, P. (2010). The Relationship between Individual Differences in Intraindividual Variability in Core Affect and Interpersonal Behavior. European Journal of Personality, 24, 623-638. https://doi.org/10.1002/per.756

Toussaint, L., \& Friedman, P. (2009). Forgiveness, Gratitude, and Well-Being: The Mediating Role of Affect and Beliefs. Journal of Happiness Studies, 10, 635-654. https://doi.org/10.1007/s10902-008-9111-8

Toussaint, L., Shields, G. S., Dorn, G., \& Slavich, G. M. (2016a). Effects of Lifetime Stress Exposure on Mental and Physical Health in Young Adulthood: How Stress Degrades and Forgiveness Protects Health. Journal of Health Psychology, 21, 1004-1014.

https://doi.org/10.1177/1359105314544132 
Toussaint, L., Worthington, E. L., Van Tongeren, D. R., Hook, J., Berry, J. W., Shivy, V. A., Miller, A. J., \& Davis, D. E. (2016b). Forgiveness Working: Forgiveness, Health, and Productivity in the Workplace. American Journal of Health Promotion, 32, 59-67. https://doi.org/10.1177/0890117116662312

Tripp, T. M., \& Bies, R. J. (1997). What's Good about Revenge: The Avenger's Perspective. In R. J. Lewicki, R. J. Bies, \& B. H. Sheppard (Eds.), Research on Negotiation in Organizations (Vol. 6, pp. 145-160). Greenwich, CT: JAI.

Trope, Y., \& Gaunt, R. (2005). Attribution and Person Perception. In M. A. Hogg, \& J. Cooper (Eds.), Handbook of Social Psychology (pp. 190-208). London: Sage.

Tsang, J., McCullough, M., \& Fincham, F. D. (2006). Forgiveness and the Psychological Dimension of Reconciliation: A Longitudinal Analysis. Journal of Social and Clinical Psychology, 25, 404-428. https://doi.org/10.1521/jscp.2006.25.4.448

Tse, W. S., \& Yip, T. H. J. (2009). Relationship among Dispositional Forgiveness of Others, Interpersonal Adjustment and Psychological Well-Being: Implication for Interpersonal Theory of Depression. Personality and Individual Differences, 46, 365-368. https://doi.org/10.1016/j.paid.2008.11.001

Unanue, W., Gómez, M. E., Cortez, D., Oyanedel, J. C., \& Mendiburo-Seguel, A. (2017). Revisiting the Link between Job Satisfaction and Life Satisfaction: The Role of Basic Psychological Needs. Frontier Psychology, 8, 680. https://doi.org/10.3389/fpsyg.2017.00680

Van Doorn, E. A., van Kleef, G. A., \& van der Pligt, J. (2015). Deriving Meaning from Others' Emotions: Attribution, Appraisal, and the Use of Emotions as Social Information. Frontiers in Psychology, 6, 1077. https://doi.org/10.3389/fpsyg.2015.01077

Van Droogenbroeck, F., Spruyt, B., \& Vanroelen, C. (2014). Burnout among Senior Teachers: Investigating the Role of Workload and Interpersonal Relationships at Work. Teaching and Teacher Education, 43, 99-109. https://doi.org/10.1016/j.tate.2014.07.005

Van Houtte, M. (2006). Tracking and Teacher Satisfaction: Role of Study Culture and Trust. Journal of Educational Research, 99, 247-254. https://doi.org/10.3200/JOER.99.4.247-256

Van Maele, D., Moolenaar, N. M., \& Daly, A. J. (2015). All for One and One for All: A Social Network Perspective on the Effects of Social Influence on Teacher Trust. In M. DiPaola, \& W. K. Hoy (Eds.), Leadership and School Quality (pp. 171-196). Charlotte, NC: Information Age Publishing.

Veldman, I., Van Tartwijk, J., Brekelmans, M., \& Wubbels, T. (2013). Job Satisfaction and Teacher-Student Relationships across the Teaching Career: Four Case Studies. Teaching and Teacher Education, 32, 55-65. https://doi.org/10.1016/j.tate.2013.01.005

Wang, H., \& Hall, N. C. (2018). A Systematic Review of Teachers' Causal Attributions: Prevalence, Correlates, and Consequences. Frontiers in Psychology, 9, 2305. https://doi.org/10.3389/fpsyg.2018.02305

Webb, J. R., Bumgarner, D. J., Conway-Williams, E., Dangel, T., \& Hall, B. B. (2017). A Consensus Definition of Self-Forgiveness: Implications for Assessment and Treatment. Spirituality in Clinical Practice, 4, 216-227. https://doi.org/10.1037/scp0000138

Wee, J. R. H. (2017). How and When Do Attributions Affect Relationship Satisfaction? Judgments of Partner Suitability and Implicit Theories of Relationships. Dissertations and Theses Collection. https://ink.library.smu.edu.sg/etd_coll_all/42

Weiner, B. (1992). Human Motivation: Metaphors, Theories and Research. London: Sage.

Weiner, B. (1995). Judgments of Responsibility: A Foundation for a Theory of Social Conduct. New York: Guilford.

Weiner, B. (2001). Intrapersonal and Interpersonal Theories of Motivation from an At- 
tributional Perspective. Educational Psychology Review, 12, 1-14. https://doi.org/10.1023/A:1009017532121

Weiner, B. (2002). Social Emotions and Personality Inferences: A Scaffold for a New Direction in the Study of Achievement Motivation. Key Speech at the 8th WATM \& Motivation and Emotion Conference, Moscow, June, 12-15.

Weiner, B. (2005). Motivation from an Attribution Perspective and the Social Psychology of Perceived Competence. In A. J. Elliot, \& C. S. Dweck (Eds.), Handbook of Competence and Motivation (pp. 73-84). New York: Guilford.

Weiner, B. (2006). Social Motivation, Justice, and the Moral Emotions: An Attributional Approach. Mahwah, NJ: Lawrence Erlbaum. https://doi.org/10.4324/9781410615749

Weiner, B. (2010). The Development of an Attribution-Based Theory of Motivation: A History of Ideas. Educational Psychology, 45, 28-36. https://doi.org/10.1080/00461520903433596

Weiner, B. (2014). The Attribution Approach to Emotion and Motivation: History, Hypotheses, Home Runs, Headaches/Heartaches. Emotion Review, 6, 353-361. https://doi.org/10.1177/1754073914534502

Weiss, H. M. (2002). Deconstructing Job Satisfaction: Separating Evaluations, Beliefs and Affective Experiences. Human Resource Management Review, 12, 173-194. https://doi.org/10.1016/S1053-4822(02)00045-1

Wenzel, M., Turner, J. K., \& Okimoto, T. G. (2010). Is Forgiveness an Outcome or Initiator of Sociocognitive Processes? Rumination, Empathy, and Cognitive Appraisals Following a Transgression. Social Psychological and Personality Science, 1, 369-377. https://doi.org/10.1177/1948550610376598

Williams, B., \& Gilmore, J. (2008). Annotation: Sociometry and Peer Relationships. Journal of Child Psychology and Psychiatric, 35, 997-1013. https://doi.org/10.1111/j.1469-7610.1994.tb01806.x

Witvliet, C. V. O., Phipps, K. A., Feldman, M. E., \& Beckham, J. C. (2004). Posttraumatic Mental and Physical Health Correlates of Forgiveness and Religious Coping in Military Veterans. Journal of Traumatic Stress, 17, 269-273. https://doi.org/10.1023/B:JOTS.0000029270.47848.e5

Wohl, M. J., DeShea, L., \& Wahkinney, R. L. (2008). Looking Within: Measuring State Self-Forgiveness and Its Relationship to Psychological Well-Being. Canadian Journal of Behavioural Science, 40, 1-10. https://doi.org/10.1037/0008-400x.40.1.1.1

Wubbels, T., Brekelmans, M., den Brok, P., Levy, J., Mainhard, T., \& van Tartwijk, J. (2012). Let's Make Things Better: Development in Research on Interpersonal Relationships in Education. In T. Wubbels, P. den Brok, J. van Tartwijk, \& J. Levy (Eds.), Interpersonal Relationships in Education: An Overview of Contemporary Research (pp. 225-250). Rotterdam: Sense. https://doi.org/10.1007/978-94-6091-939-8

Ybarra, O., \& Stephan, W. G. (1999). Attributional Orientation and the Prediction of Behavior: The Attribution-Prediction Bias. Journal of Personality and Social Psychology, 76, 718-727. https://doi.org/10.1037/0022-3514.76.5.718

Yoon, J. S. (2002). Teacher Characteristics as Predictors of Teacher-Student Relationships: Stress, Negative Affect, and Self-Efficacy. Social Behavior and Personality, 30, 485-493. https://doi.org/10.2224/sbp.2002.30.5.485

Zandvliet, D., den Brok, P., Mainhard, T., \& van Tartwijk, J. W. F. (2014). Interpersonal Relationships in Education: From Theory to Practice. Rotterdam: Sense. https://doi.org/10.1007/978-94-6209-701-8 